\title{
The Effect of Pyrroloquinoline Quinone on the Expression of WISP1 in Traumatic Brain Injury
}

\author{
Yongqi Ye, Pengju Zhang, Yuhang Qian, Baoxin Yin, and Meijuan Yan \\ The Jiangsu Key Laboratory of Neuroregeneration, Nantong University, 19 Qixiu Road, Nantong 226001, China \\ Correspondence should be addressed to Meijuan Yan; ymz@ntu.edu.cn
}

Received 11 March 2017; Accepted 30 May 2017; Published 14 August 2017

Academic Editor: Hailiang Tang

Copyright (C) 2017 Yongqi Ye et al. This is an open access article distributed under the Creative Commons Attribution License, which permits unrestricted use, distribution, and reproduction in any medium, provided the original work is properly cited.

\begin{abstract}
WISP1, as a member of the CCN4 protein family, has cell protective effects of promoting cell proliferation and inhibiting cell apoptosis. Although some studies have confirmed that WISP1 is concerned with colon cancer and lung cancer, there is little report about the influence of WISP1 in traumatic brain injury. Here, we found that the expression of WISP1 mRNA and protein decreased at $3 \mathrm{~d}$ and then increased at $5 \mathrm{~d}$ after traumatic brain injury (TBI). Meanwhile, immunofluorescence demonstrated that there was little colocation of WISP1 with GFAP, Iba1, and WISP1 colocalized with NeuN partly. WISP1 colocalized with LC3, but there was little of colocation about WISP1 with cleaved caspase-3. Subsequent study displayed that the expression of $\beta$-catenin protein was identical to that of WISP1 after TBI. WISP1 was mainly located in cytoplasm of PC12 or SHSY5Y cells. Compared with the negative control group, WISP1 expression reduced obviously in SHSY5Y cells transfected with WISP1 si-RNA. CCK-8 assay showed that pyrroloquinoline quinone (PQQ) had little influence on viability of PC12 and SHSY5Y cells. These results suggested that WISP1 played a protective role after traumatic brain injury in rats, and this effect might be relative to autophagy caused by traumatic brain injury.
\end{abstract}

\section{Introduction}

Traumatic brain injury (TBI), also known as brain injury, is mainly caused by external mechanical forces. There were a series of pathological, physiological, and biochemical changes, such as subarachnoid hemorrhage, cerebral blood tube spasms, disturbance of cerebral circulation, and cerebral edema. All these secondary and primary brain injuries led to higher mortality rates. In the present study, Feeney et al.'s [1] method was used to establish a traumatic brain injury (TBI) model in rats.

WISP1 (Wnt1 inducible signaling pathway protein 1) is a CCN family member, which is more broadly identified with development and tumorigenesis [2]. CCN protein family consists of 6 family members, including cysteine-rich protein 61 (CYR61/CNN1) and connective tissue growth factor (CTGF/CCN2), as well as nephroblastoma-overexpressed secreted protein (NOV/CCN3), WISP1 (CCN4), WISP2 (CCN5), and WISP3 (CCN6) [3]. The CCN family is characterized by four cysteine-rich modular domains that include insulin-like growth factor-binding domain, von Willebrand factor type $\mathrm{C}$ module, thrombospondin domain, and C-terminal cysteine knot-like domain. In the extracellular matrix, WISP1 combinates leucine-rich proteoglycans and affects ability of the cell to anchor the extracellular matrix [4].

WISP1 could express in a variety of tissues, and there is no tissue specialty. Pennica et al. discovered that WISP1 was expressed in many tissues including the adult heart, lung, kidney, small intestine, spleen, pancreas, ovaries, and brain, but there were significance changes about express levels among different tissues [5]. WISP1 could block p53mediated DNA damage and apoptosis [6] and promote cell proliferation and cell adhesion [7]. WISP1 was associated with neoplastic growth [8]. WISP1 has a relationship with the formation and evolution of lung cancer, renal cell carcinoma, colorectal cancer, and other tumors. In the recent years, study showed that WISP1 could promote cardiac remodeling following myocardial infarction [7] and lung 
tissue repair and regrowth [9]. In addition, WISP1 may play a vital role in bone formation and fracture repair $[10,11]$ and can limit neuronal cell injury during oxidative stress [12].

$\beta$-Catenin is a soluble protein located in the cytoplasm which is first found in 1980 by German scientists [13]. Subsequent studies show that $\beta$-catenin is homology analogs of armadillo gene of Drosophila in mammals [14]. Intracellular $\beta$-catenin mainly exists in the cell membrane, cytoplasm, or nucleus in complex forms. The location of $\beta$-catenin in the cell is related to biological functions. For $\beta$-catenin in cell membrane, $\beta$-catenin protein in normal mature cells mediated cell adhesion and migration and affected the polarity and integrity of the epithelium [15]. $\beta$-Catenin in the cytoplasm passes through into the nuclear, leading to gene transcription, which is closely related to the development and progression of many diseases [16]. $\beta$-Catenin in the nucleus promotes transcription of downstream target genes, which accelerate the cell cycle, promote cell proliferation, produce abnormal protein, and eventually lead to the occurrence of tumor [17].

WISP1, as a CCN family member, utilizes protective pathways that include the traditional wingless canonical and noncanonical signaling of Wnt1. In addition, WISP1 can increase the nuclear expression of $\beta$-catenin [4]. Interestingly, study finds that $\beta$-catenin can promote the expression of WISP1 by Wnt1 signaling [18]. WISP1 and its signaling pathways with $\beta$-catenin represent a novel target that has the potential ability to promote tissue proliferation, repair, and regeneration in multiple cell systems $[4,19,20]$.

Pyrroloquinoline quinone (PQQ) is a new oxidoreductase coenzyme which was discovered in the late 1970 of the 20th century. And it is an anionic water soluble compound which exists in almost all biological tissues [21]. PQQ has also been attended broadly in nutrition and pharmacology as an important antioxidant or nutrient. Numerous studies have shown that PQQ has many other pharmacological effects, such as anti-inflammatory and liver and heart protection [22]. It is reported that PQQ-deficient diet cause impaired growth, immunological defects, and decreased fertility in mice [23].

Recent studies have shown that PQQ alters intracellular signaling pathways. For example, when the phosphatidylinositol-3-kinase (PI3K)/AKT signaling pathways are blocked, the protective effects of PQQ will be lost, which implicates that PQQ could regulate neuronal cell survival by (PI3K)/AKT signaling pathway [24]. Similarly, WISP1 has been shown to rely on PI3K and AKT to provide cytoprotection in neurons $[4,12]$. WISP1 ultimately modulates apoptotic pathways of Bad, glycogen synthase kinase-3 $\beta$ (GSK-3 $\beta$ ), Bim, Bcl-xL, mitochondrial membrane permeability, cytochrome $\mathrm{c}$ release, and caspase activation to prevent cell injury [12]. PI3K and AKT are critical pathways to foster cellular proliferation and block apoptotic injury. However, whether WISP1 can be affected by the activation of PQQ by PI3K/AKT has not been reported.

Although many experiments have confirmed that WISP1 has obvious effective on tissue proliferation, repair, and regeneration, there is little report about the effect of WISP1 in traumatic brain injury. In the present study, we try to explore the effect of WISP1 protein on cell expression, which is necessary to treat brain injury by understanding brain injury repair processes. Therefore, we have established a rat model of TBI to try to further research the function of WISP1 in traumatic brain injury.

\section{Materials and Methods}

2.1. Animals and the TBI Model. Sprague-Dawley (SD) rats (200-250 g) were obtained from the Experimental Animal Center of Nantong University (Nantong, China). All animals $(n=117)$ were divided into thirteen groups: sham, $1 \mathrm{~d}, 3 \mathrm{~d}, 5 \mathrm{~d}$, and $7 \mathrm{~d}$ post-TBI and $1 \mathrm{~d}, 3 \mathrm{~d}, 5 \mathrm{~d}$, and $7 \mathrm{~d}$ post-TBI $+1 \mathrm{mM}$ PQQ or $2 \mathrm{mM}$ PQQ. Referring to Feeney et al.'s [1] TBI method model, briefly, the rats were deeply anesthetized with chloral hydrate (10\% solution), and the heads were fixed in the stereotactic frame, and a $10 \mathrm{~mm}$ diameter craniotomy were performed adjacent to the central suture, midway between the lambda and the bregma. The dura was kept intact over the cortex. Injury was delivered by impacting the right cortex with a fluid percussion brain injury device (AmScien Instruments, Richmond, USA). Sham rats $(n=9)$ were craniotomized only. After all the procedures, animals were returned to their cages and allowed freely to get the food and water. Animals were housed under a $12 \mathrm{~h}$ light/dark cycle, and room temperature was kept at $25 \pm 0.5^{\circ} \mathrm{C}$.

2.2. Real-Time PCR Analysis. Total RNA was extracted from the frozen cortex brain tissues with TRIZOL Reagent (Sigma) according to the manufacturer's recommendations. The RNA was reverse-transcribed to cDNA using reverse transcription kit (Thermo) with oligo $(\mathrm{dT})_{18}$ primers. Primers of WISP1 and GAPDH were designed with primer 5 software and synthesized by biotech company (GENEray, Shanghai, China), WISP1 sense primer: 5'-GCCCGAGGTACGCAATAGGAGT-3' and antisense primer: 5'-CCCACGGTGCCATCAATACAGG-3'; GAPDH sense primer was also designed in same way, GAPDH sense primer: 5'-CAACGGGAAACCCATCACCA-3' and antisense primer: 5'-ACGCCAGTAGACTCCACGACAT-3'. Quantitative real-time PCR analysis was performed using the LightCycler 96 (Roche), applying real-time SYBR Green PCR technology (Roche). The reaction mixtures contained $5 \mu \mathrm{l}$ SYBR Master Mix, $0.1 \mu \mathrm{l}$ of each PCR forward and reverse primer $(10 \mu \mathrm{M}), 1 \mu \mathrm{l} \mathrm{cDNA}$, and $3.9 \mu \mathrm{l}$ nuclease-free water for a final volume of $10 \mu \mathrm{l}$. After one cycle of $95^{\circ} \mathrm{C}$ for $10 \mathrm{~min}$, 45 PCR cycles were performed, each consists of a denaturation step $\left(95^{\circ} \mathrm{C}, 10 \mathrm{~s}\right)$ and an annealing step $\left(60^{\circ} \mathrm{C}, 30 \mathrm{~s}\right)$. Total RNA concentrations from each sample were normalized by the quantity of GAPDH mRNA. All experiments were repeated at least three times.

2.3. Western Blot. The brain tissues were stored in $-80^{\circ} \mathrm{C}$; tissue samples were lysed with extraction buffer. Concentration of the protein was tested using bicinchoninic acid assay kit (Beyotime, Jiangsu, China), followed by electrophoresis separation on SDS-PAGE, and then transferred to a PVDF membrane (Millipore, Bedford, MA, USA) for $120 \mathrm{~min}$ at $100 \mathrm{~V}$. The membranes were blocked with 5\% skim milk 
and then incubated overnight with WISP1 antibody (diluted 1:500 in TBS; Santa Cruz, Cell Signaling Technology), $\beta$ actin $(1: 4000$, Sigma), and $\beta$-catenin $(1: 500$, Santa Cruz). The PVDF membrane was washed with TBST (TBS with $0.1 \%$ Tween 20 ) for $10 \mathrm{~min}$ at least three times and incubated with corresponding HRP-conjugated secondary antibody for $2 \mathrm{~h}$ at room temperature. After washing the PVDF membrane for $10 \mathrm{~min}$ at least 3 times, the protein was visualized using Beyo ECL Star (Beyotime, Jiangsu, China).

2.4. Immunofluorescence. The brain tissue was fixed with $4 \%$ paraformaldehyde at $4^{\circ} \mathrm{C}$, after the brain tissues sink to the bottom of the bottle and after dehydrating by concentration of gradient $(10 \%, 20 \%, 30 \%$, and $5 \%)$, and then, $12 \mu \mathrm{m}$ frozen sections were prepared and examined. All sections were blocked with blocking solution (10\% goat serum, 3\% BSA, and $0.1 \%$ Triton $\mathrm{X}-100$ ) for $1 \mathrm{~h}$ at $37^{\circ} \mathrm{C}$, incubating overnight with antibody WISP1 (diluted 1:500; Santa Cruz), antiGFAP (1:400; BD Pharmingen), anti-NeuN (1:1000; Abcam), $\beta$-catenin (1:500; Santa Cruz), anti-cleaved caspase-3 (1:400; Cell Signaling Technology), anti-LC3 (1:500; Cell Signaling Technology), and anti-Iba1 (1:1000; Wako) and then washing them with $0.01 \mathrm{M}$ PBS for $10 \mathrm{~min}$ at 3 times and followed by incubating with a mixture of FITCor Cy3-conjugated secondary antibodies for $2 \mathrm{~h}$ at room temperature and then being washed again in PBS for $10 \mathrm{~min}$ at 3 times. The stained sections were examined with a Leica fluorescence microscope (Leica DM 5000B, Germany).

2.5. EdU Assay. Cell proliferation was detected by Cell-Light EdU DNA cell proliferation kit (RiboBio, Guangzhou, China) according to the manufacturer's instructions. Astrocytes were cultured into 96-well plates at $4 \times 10^{4}$ cells/well. After being incubated with $50 \mu \mathrm{M}$ EdU for $24 \mathrm{~h}$, cells were washed with PBS, followed by fixation in $4 \%$ formaldehyde for $30 \mathrm{~min}$, then being permeabilizated in $0.5 \%$ Triton X100 for $10 \mathrm{~min}$. After extensive washing with PBS, cells were incubated with Apollo for $30 \mathrm{~min}$ and Hoechst for $30 \mathrm{~min}$. Proliferative cells was calculated as the percentage of EdUpositive cells relative to the total number of cells.

2.6. Transwell Migration Assay. Astrocytes were cultured at $4 \times 10^{3}$ cells/well with DMEM in the upper chamber of a 24-well transwell chamber with $8 \mu \mathrm{m}$ pore size polycarbonate filters (Costar). 10\% fibronectin was added in the lower chamber as chemoattractant. Astrocytes migrate for $24 \mathrm{~h}$ and then followed by fixation in $4 \%$ formaldehyde for $1 \mathrm{~h}$ and stained with $0.1 \%$ crystal violet. Images were taken with a microscope and five fields were counted.

2.7. Cell Culture. The SHSY5Y and PC12 cells were obtained from the Chinese Academy of Sciences (Shanghai, China). The cells were cultured in DMEM with $10 \% \mathrm{FBS}$ at $37^{\circ} \mathrm{C}$ in an incubator containing $5 \% \mathrm{CO}_{2}$.

2.8. Transfection. To silence the expression of WISP1 gene, WISP1 si-RNA was obtained (Invitrogen), WISP1 sense primer: 5'-GGACAUCCAUACACUCAUUTT-3' and antisense primer: 5'-AAUGAGUGUAUGGAUGUCCTT-3'. siRNA transfection was performed with lipofectamine 3000
(Invitrogen) according to the manufacturer's guidelines. All data were obtained after being transfected for $72 \mathrm{~h}$.

2.9. CCK-8 Test. SHSY5Y cells and PC12 cells were seeded onto 96-well plate ahead of time and then treated with different concentrations of PQQ for $24 \mathrm{~h}$. Subsequently, cells were incubated in a humidified atmosphere with $5 \% \mathrm{CO}_{2}$ at $37^{\circ} \mathrm{C}$ for $2 \mathrm{~h}$ after adding CCK-8 test solution (Dojindo, Japan), and the cell viability were detected by using microplate reader at $450 \mathrm{~nm}$.

2.10. Statistical Analysis. For each experiment, the mean and standard error were determined. The data were analyzed by means of analysis of variance (one-way ANOVA). Statistical significance was determined at the level of $P<0.05$.

\section{Results}

3.1. Expression and Localization of WISP1 after TBI. In order to observe the WISP1 mRNA expression after TBI, qRT-PCR was performed. The results showed that, compared with the sham group, WISP1 mRNA slightly decreased at $1 \mathrm{~d}$, reached the minimum at $3 \mathrm{~d}$ after TBI, and then recovered at $5 \mathrm{~d}$ and $7 \mathrm{~d}$ after TBI. Meanwhile, $1 \mathrm{mM}$ or $2 \mathrm{mM}$ PQQ increased WISP1 mRNA expression at $3 \mathrm{~d}, 5 \mathrm{~d}$, and $7 \mathrm{~d}$ post-TBI, but the effect of $1 \mathrm{mM}$ PQQ was obvious to the $2 \mathrm{mM}$ PQQ (Figure 1).

To investigate the cell type that WISP1 located, doublelabeling immunofluorescence was performed. The colocalizations of WISP1 with astrocyte marker GFAP, neuronal marker NeuN, microglia marker Ibal were examined respectively. Compared with the sham group, WISP1-positive signals decreased slightly in the control lateral brain and reduced significantly in the ipsilateral brain. However, GFAP positive signals increased slightly in the control lateral brain and had a dramatic increase in the ipsilateral brain. There was a little amount colocalization between WISP1 and GFAP in the sham group. However, obvious colocalizations were observed in the brain at $3 \mathrm{~d}$ after TBI including ipsilateral and control lateral brain (Figure 2).

NeuN-positive signals obviously decreased in the ipsilateral brain and decreased slightly in the control lateral brain compared with the sham group (Figure 3). Doublelabeling immunofluorescence demonstrated that there were obvious colocations of WISP1 and NeuN either in ipsilateral or in control lateral brain after TBI at $3 \mathrm{~d}$ compared with the sham group.

At the same time, there was a modicum colocation of WISP1 and Iba1. Compared with the sham group, Iba1positive signals increased substantially in the ipsilateral brain (Figure 4).

3.2. WISP1 and the Relationship between Autophagy and Apoptosis. Brain injury was often accompanied by the occurrence of apoptosis and autophagy. In the present study, double immunofluorescence was used to detect the colocalization of WISP1 and autophagy marker LC3 and apoptosis marker cleaved caspase-3. Compared with the sham group, LC3positive signals had a substantial increase in the ipsilateral brain and had no significant change in the control lateral 


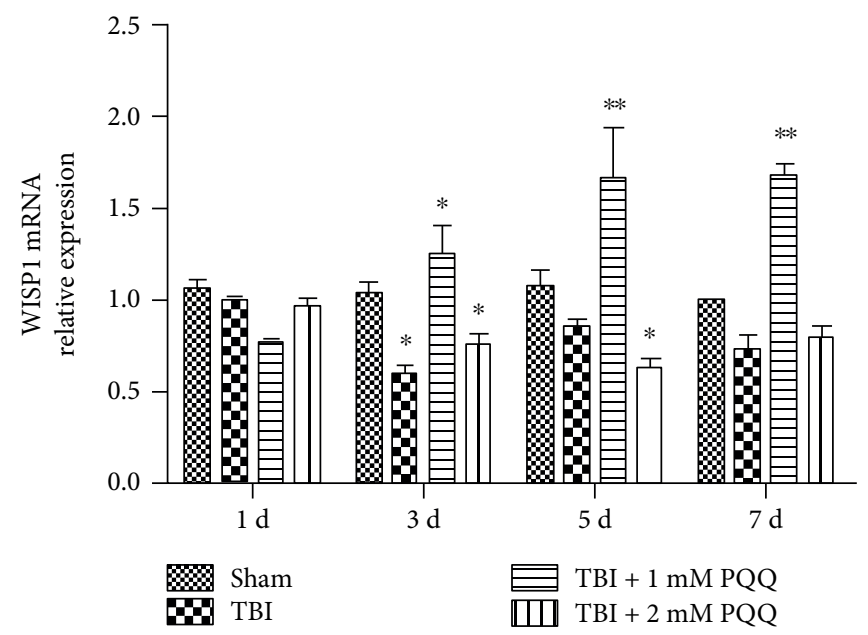

Figure 1: The expression of WISP1 mRNA after TBI $\left({ }^{*} P<0.05,{ }^{* *} I<0.01\right.$ versus sham). $1 \mathrm{~d}$ : ipsilateral $1 \mathrm{~d}$ post-TBI group; $3 \mathrm{~d}$ : ipsilateral $3 \mathrm{~d}$ post-TBI group; $5 \mathrm{~d}$ : ipsilateral $5 \mathrm{~d}$ post-TBI group; $7 \mathrm{~d}$ : ipsilateral $7 \mathrm{~d}$ post-TBI group.
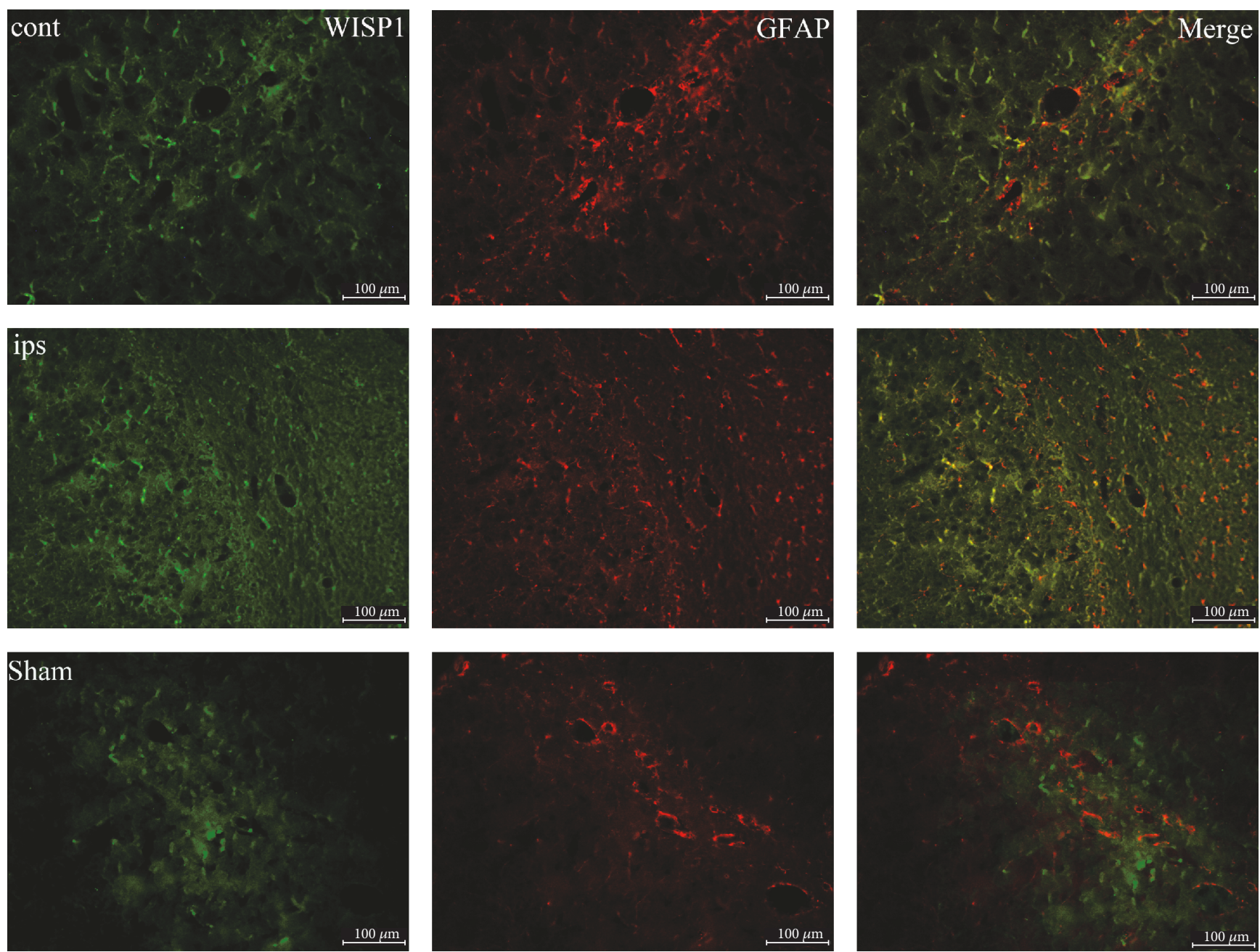

FIgURE 2: Double-labeling immunofluorescence of WISP1 and GFAP at $3 \mathrm{~d}$ after TBI. Green: WISP1; red: GFAP; cont: the control of ipsilateral $3 \mathrm{~d}$ post-TBI group; ips: ipsilateral $3 \mathrm{~d}$ post-TBI group; sham: sham group; bar $=100 \mu \mathrm{m}$. 

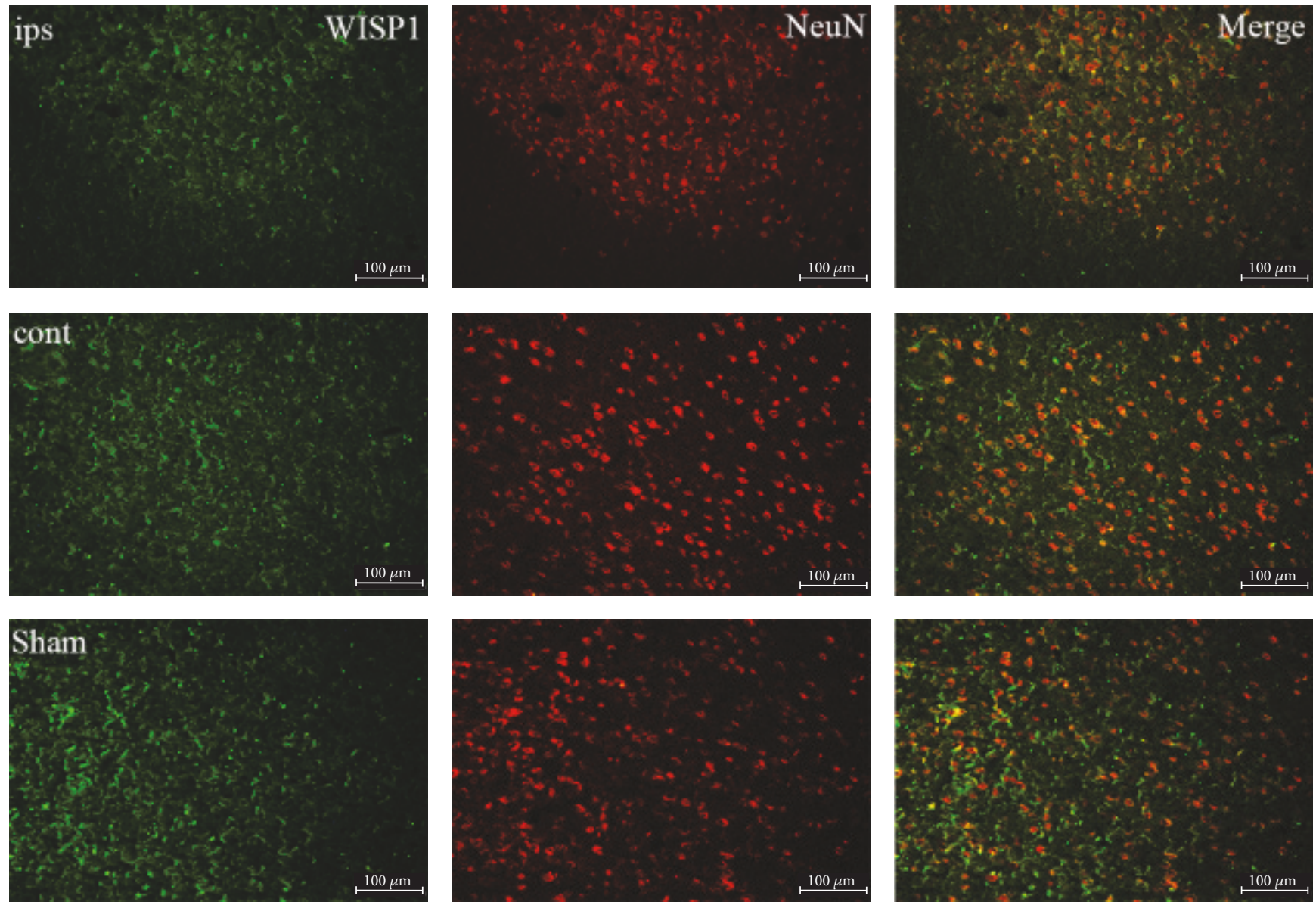

FIgURE 3: Double-labeling immunofluorescence of WISP1 and NeuN at $3 \mathrm{~d}$ after TBI. Green: WISP1; red: NeuN; cont: the control of ipsilateral $3 \mathrm{~d}$ post-TBI group; ips: ipsilateral $3 \mathrm{~d}$ post-TBI group; sham: sham group; bar $=100 \mu \mathrm{m}$.

brain after $3 \mathrm{~d}$ post-TBI. After treatment with $1 \mathrm{mM}$ PQQ at $3 \mathrm{~d}$ post-TBI, WISP1-positive signals rose obviously; LC3 positive signals declined markedly in the ipsilateral brain. Double-labeling immunofluorescence showed that there were a lot of colocalization of WISP1 and LC3 (Figure 5).

After $3 \mathrm{~d}$ post-TBI, compared with the sham group, cleaved caspase-3 expression was obviously upregulated in the ipsilateral brain and had no significant change in the control lateral brain. After treatment with $1 \mathrm{mM}$ PQQ at $3 \mathrm{~d}$ post-TBI, cleaved caspase-3-positive signals declined obviously in the ipsilateral brain. Double-labeling immunofluorescence showed that there was a little colocalization of WISP1 and cleaved caspase-3 (Figure 6).

3.3. The Relationship of WISP1 and $\beta$-Catenin. The expression changes of WISP1 and $\beta$-catenin protein were performed by Western blot, which indicated that the protein expression trend of WISP1 was similar to that of $\beta$-catenin at different time points after TBI. The protein expression of WISP1 and $\beta$-catenin decreased slightly at $1 \mathrm{~d}$ after TBI, minimized at $3 \mathrm{~d}$ post-TBI and rose again at $5 \mathrm{~d}$ after TBI, and slightly reduced at $7 \mathrm{~d}$ after TBI compared with the sham group (Figure 7(a)). Meanwhile, the treatment with $1 \mathrm{mM}$ PQQ increased the protein expression of WISP1 and $\beta$ catenin at $3 \mathrm{~d}, 5 \mathrm{~d}$, and $7 \mathrm{~d}$ post-TBI (Figure $7(\mathrm{~b})$ ). When
$2 \mathrm{mM}$ PQQ was treated, there was no obvious change trend (Figure 7(c)).

After $3 \mathrm{~d}$ post-TBI, as far as the sham group, WISP1 expression significantly reduced in the ipsilateral brain and slightly reduced in the control brain. Moreover, $\beta$-cateninpositive signal change trend was similar to that of WISP1. Double-labeling immunofluorescence showed that there was a lot colocalization of WISP1 with $\beta$-catenin (Figure 8).

The PI3K inhibitor LY294002 $(10 \mu \mathrm{M})$ and GSK-3 $\beta$ inhibitor SB21673 $(5 \mu \mathrm{M})$ with WISP1 $(10 \mathrm{ng} / \mathrm{ml})$ were administrated. The experiments showed that the expression of WISP1 reduced with the administration of glutamate and then upregulated after using $50 \mu \mathrm{M}$ PQQ as well as WISP1 protein. Interestingly, the expression of WISP1 did not increase under the glutamate after blocking the PI3K/GSK- $3 \beta$ signaling pathway, just as the $\beta$-catenin did (Figure 9).

Double-labeling immunofluorescence showed that there were a lot of colocalization of WISP1 and neuron in TBI, so SHSY5Y cells and PC12 cells were chosen to study further. Immunofluorescence displayed that WISP1 distributed in the cytoplasm either SHSY5Y cells or PC12 cells (Figure 10).

The colocalization of WISP 1 and $\beta$-catenin were detected in SHSY5Y cells or PC12 cells. Immunofluorescence showed that $\beta$-catenin was distributed in the cytoplasm of SHSY5Y 

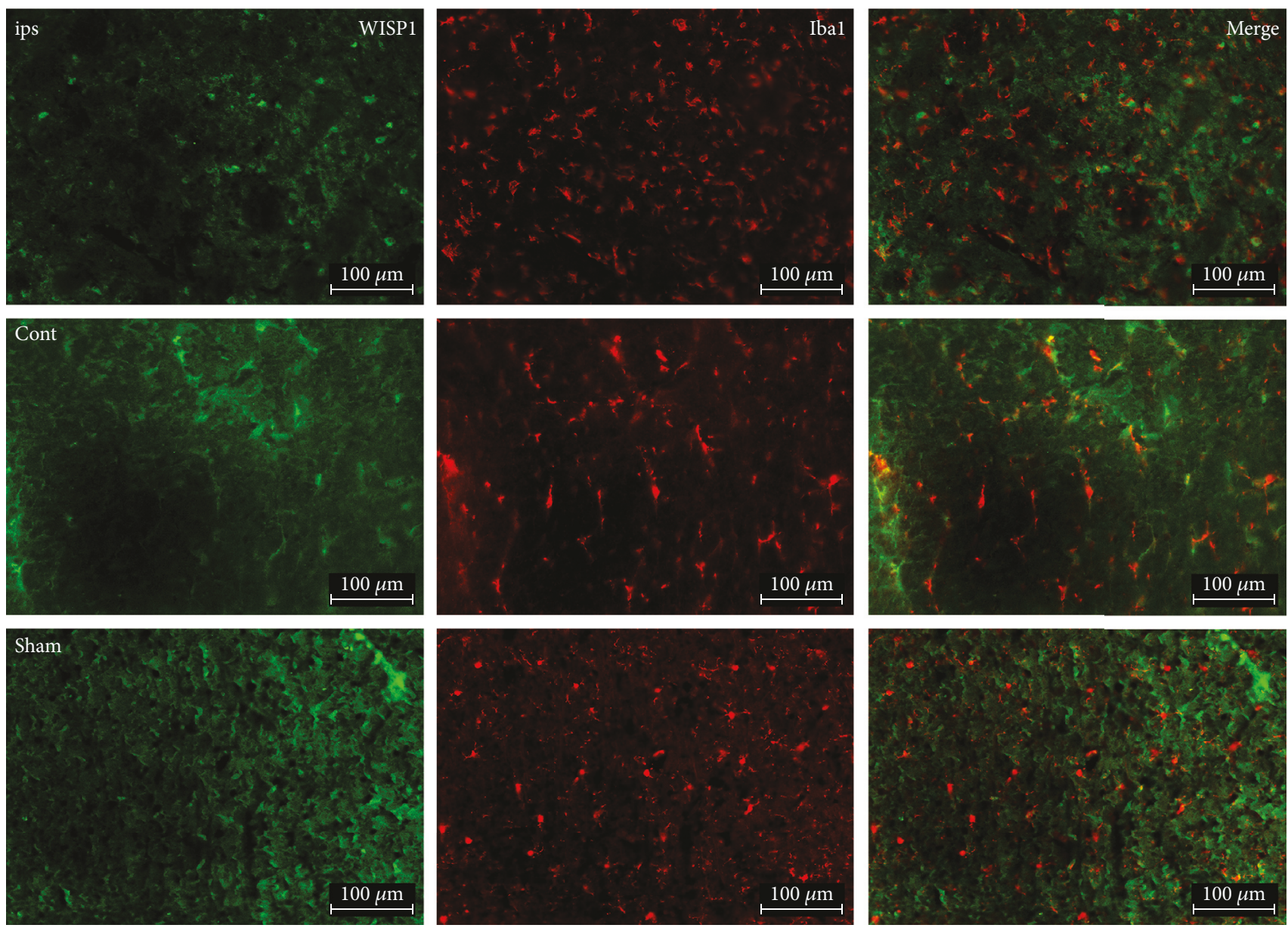

FIGURE 4: Double-labeling immunofluorescence of WISP1 and Iba1 at $3 \mathrm{~d}$ after TBI. Green: WISP1; red: Iba1; cont: the control of ipsilateral $3 \mathrm{~d}$ post-TBI group; ips: ipsilateral $3 \mathrm{~d}$ post-TBI group; sham: sham group; bar $=100 \mu \mathrm{m}$.

cells or PC12 cells, and there was obvious expression in nuclear of SHSY5Y cells. Double-labeling immunofluorescence showed that WISP1 colocalizated with $\beta$-catenin in the cytoplasm of SHSY5Y or PC12 cells (Figure 11).

3.4. The Effect of PQQ on the Viability of Cells. The effects of different concentrations or time of PQQ on the activity of PC12 and SHSY5Y cells were performed with CCK-8 assay. The results showed, incubating PC12 cells for $24 \mathrm{~h}$ with 10 , $20,30,40$, and $50 \mu \mathrm{M} P Q Q$, that there was no distinct effect on PC12 cell activity compared with the control group (Figure 12(a)). Meanwhile, the similar results were obtained in SHSY5Y cells. That is, there was no obvious change of cell viability in SHSY5Y cells treated with or without 10, 20, 30, 40 , and $50 \mu \mathrm{M}$ PQQ for $24 \mathrm{~h}$ (Figure 12(b)). When $50 \mu \mathrm{M}$ PQQ was incubated for $6 \mathrm{~h}, 12 \mathrm{~h}, 24 \mathrm{~h}$, and $48 \mathrm{~h}$ in PC12 cells, there was slight influence on PC12 cell activity at $48 \mathrm{~h}$ (Figure 12(c)). At the same time, adopting the same approach in SHSY5Y cells, the activity of SHSY5Y cells was consistent with PC12 cell activity (Figure 12(d)).

Western blot was used to detect the protein expression of WISP1 in PC12 or SHSY5Y cells that were treated with different concentrations of PQQ for $24 \mathrm{~h}$. Compared with the control group, the expression of WISP1 increased slightly with
$10 \mu \mathrm{M}$ PQQ, reached the peak in PC12 cells treated with $20 \mu \mathrm{M}$ PQQ for $24 \mathrm{~h}$, and then other groups decreased gradually. Moreover, $\beta$-catenin expression in PC12 cells peaked with $20 \mu \mathrm{M}$ PQQ for $24 \mathrm{~h}$. There was no obvious difference with 10, 30, 40, and $50 \mu \mathrm{M}$ PQQ (Figure 13(a)). Meanwhile, the similar results were obtained in SHSY5Y cells (Figure 13(b)).

$50 \mu \mathrm{M}$ PQQ was used to detect the protein expression of WISP1 in PC12 or SHSY5Y cells at 6, 12, 24, and $48 \mathrm{~h}$. Compared with the control group, results showed that the expression of WISP1 reduced gradually in a time-dependent manner and reached the minimum in PC12 cells treated with $50 \mu \mathrm{M}$ PQQ for $48 \mathrm{~h}$. $\beta$-Catenin protein expression in PC12 cells reached the minimum at $48 \mathrm{~h}$ and increased slightly at $6 \mathrm{~h}, 12 \mathrm{~h}$, and $24 \mathrm{~h}$ compared with the control group, but it was not significant $(P>0.05)$ (Figure 14(a)). At the same time, the similar results were obtained in SHSY5Y cells. The expression of WISP1 in SHSY5Y cells was similar to that of $\beta$-catenin in PC12 cells; $\beta$-catenin protein expression in SHSY5Y cells reached the minimum at $48 \mathrm{~h}$ and increased slightly at $6 \mathrm{~h}$ and $12 \mathrm{~h}$, but there was no significant difference compared with the control group $(P>0.05)$ (Figure 14(b)).

Prior to adding the glutamate, $25 \mu \mathrm{M}, 50 \mu \mathrm{M}$, and $100 \mu \mathrm{M}$ PQQ were added in the cell medium, respectively. 

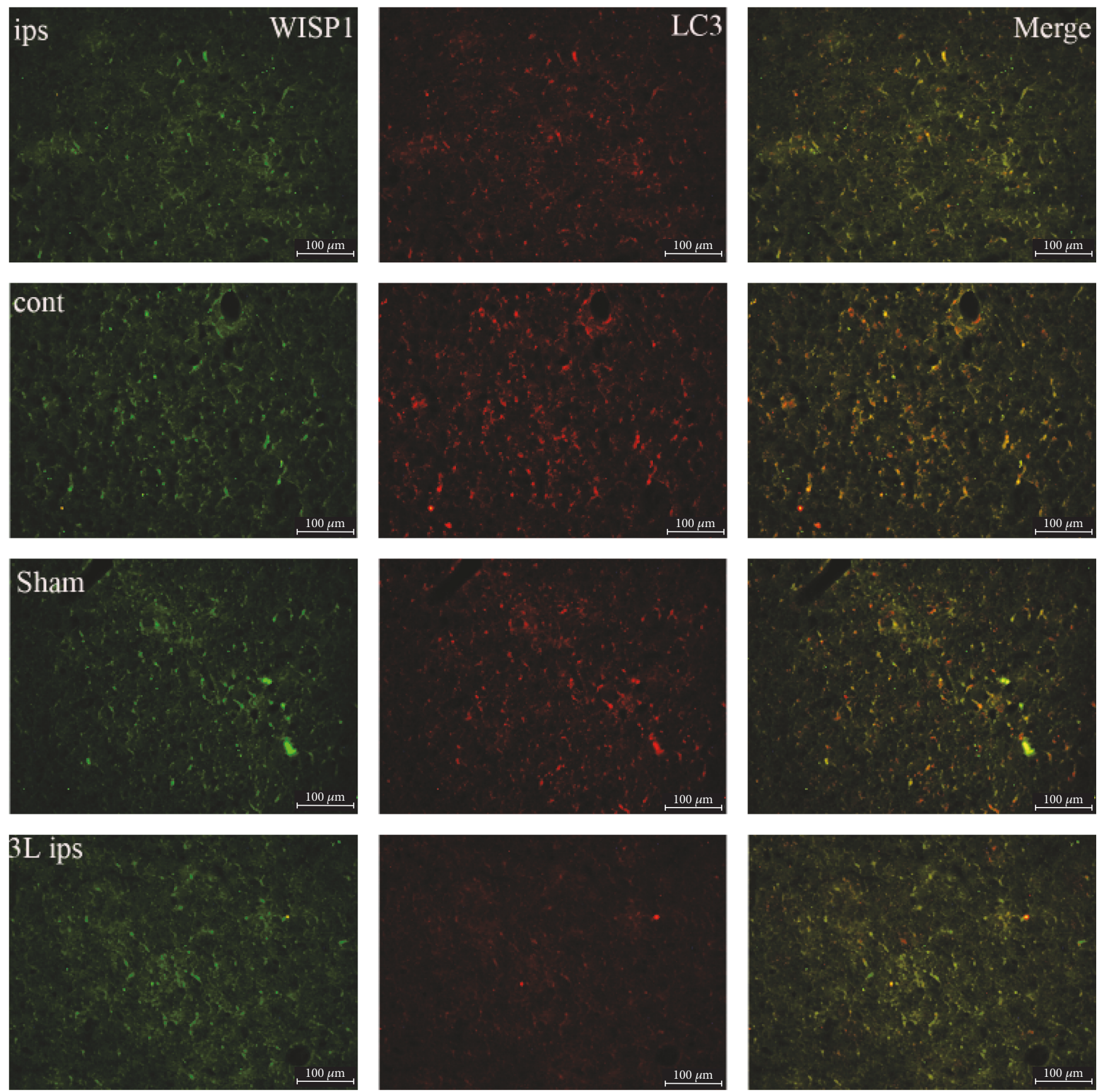

FIGURE 5: Double-labeling immunofluorescence of WISP1 and LC3 at $3 \mathrm{~d}$ after TBI. Green: WISP1; red: LC3; cont: the control of ipsilateral $3 \mathrm{~d}$ post-TBI group; ips: ipsilateral $3 \mathrm{~d}$ post-TBI group; sham: sham group; $3 \mathrm{~L}$ ips: $3 \mathrm{~d}$ post-TBI $+1 \mathrm{mM}$ PQQ group; cont: the control of ipsilateral $3 \mathrm{~d}$ post-TBI $+1 \mathrm{mM}$ PQQ group. $\mathrm{Bar}=100 \mu \mathrm{m}$.

EdU assay results showed that PQQ could promote the proliferation of astrocytes inhibited by glutamate $\left({ }^{*} P<0.05\right.$, ${ }^{* *} P<0.01$ ) (Figure 15).

Transwell migration assay demonstrated that $5 \mu \mathrm{M}$, $50 \mu \mathrm{M}$, and $100 \mu \mathrm{M}$ PQQ could reverse the astrocyte migration inhibited by glutamate $\left({ }^{*} P<0.05,{ }^{* *} P<0.01\right)$ (Figure 16 ).

To observe the function of WISP1, WISP1 si-RNA was transfected in the astrocytes. Compared with negative control group, the expression of WISP1 obviously declined after being transfected with WISP1 si-RNA for $48 \mathrm{~h}$, which suggested that WISP1 si-RNA was efficient $\left({ }^{*} P<0.05\right.$, ${ }^{* *} P<0.01$ ) (Figures 17(a), 17(b), and 17(c)).

The expression of WISP1 was silenced, and the EdU assay was performed. WISP1 could increase the positive signals of astrocytes $\left({ }^{* *} P<0.01\right)$ (Figures $17(\mathrm{~d})$ and $\left.17(\mathrm{e})\right)$. Similarly, to determine whether WISP1 plays an important role in cell migration, transwell migration assay was used to detect the migration of astrocytes; the results show that migrated cell numbers were significantly increased following interference expression of WISP1 ( $\left.{ }^{* *} P<0.01\right)$ (Figures $17(\mathrm{f})$ and $17(\mathrm{~g})$ ). 

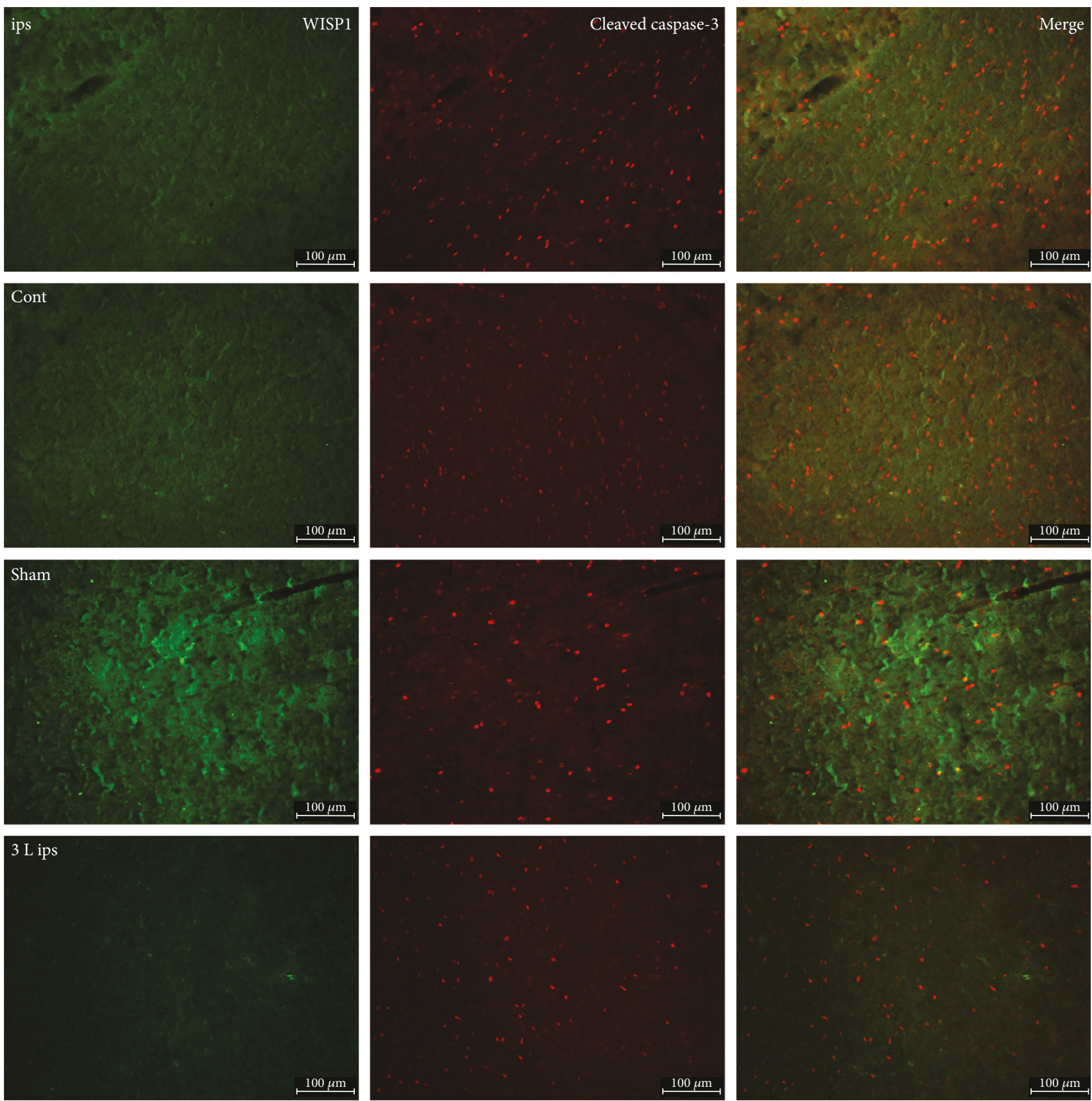

FIGURE 6: Double-labeling immunofluorescence of WISP1 and cleaved caspase- 3 at $3 \mathrm{~d}$ after TBI. Green: WISP1; red: cleaved caspase-3; cont: the control of ipsilateral $3 \mathrm{~d}$ post-TBI group; ips: ipsilateral $3 \mathrm{~d}$ post-TBI group; sham: sham group; $3 \mathrm{~L}$ ips: $3 \mathrm{~d}$ post-TBI + $1 \mathrm{mM}$ PQQ group; cont: the control of ipsilateral $3 \mathrm{~d}$ post-TBI $+1 \mathrm{mM}$ PQQ group. Bar $=100 \mu \mathrm{m}$.

\section{Discussion}

Traumatic brain injury (TBI) is mainly caused by an external mechanical force, which can be divided into primary and secondary damage. TBI can be classified based on the severity or mechanism of injury, as well as other features. In most cases, TBI leads to higher mortality rates and disability; moreover, TBI could cause physical, pathological, and behavioral effects. Therefore, more and more people attracted general attention. Protecting neurons are the main methods to treat cerebral trauma, and the treatment goals are focused in the cell death program targets. However, there is not an effective method to treat TBI so far.

WISP1 is a family of secreted proteins and regulate various developmental processes. Wnt1 proteins combine the cell membrane receptor by autocrine or paracrine effects, activate intracellular signaling pathways, regulate target gene expression, and play an important role on cell proliferation, polarity and differentiation, and migration. WISP1 secreted Wnt1-induced protein 1, also known as CCN4, cognating connective tissue growth factor (CTGF) [2]. WISP1 was later associated with neoplastic growth 


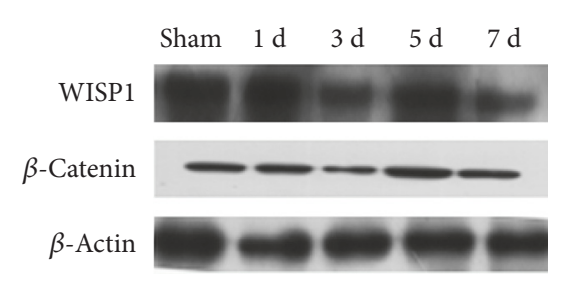

(a)

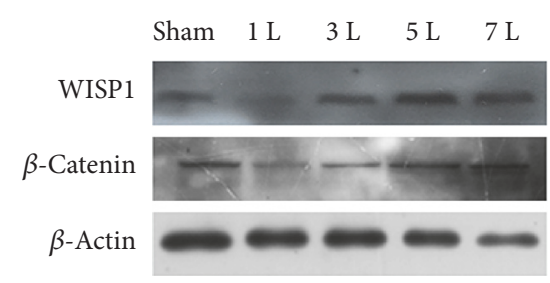

(b)

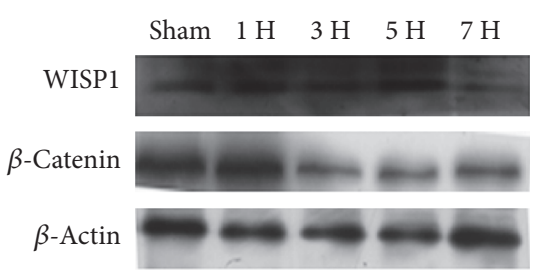

(c)

FIGURE 7: WISP1 and $\beta$-catenin protein expression $(P<0.05, P<0.01)$. Sham: sham group; $1 \mathrm{~d}$ : ipsilateral $1 \mathrm{~d}$ post-TBI group; $3 \mathrm{~d}$ : ipsilateral $3 \mathrm{~d}$ post-TBI group; $5 \mathrm{~d}$ : ipsilateral $5 \mathrm{~d}$ post-TBI group; $7 \mathrm{~d}$ : ipsilateral $7 \mathrm{~d}$ post-TBI group; $1 \mathrm{~L}$ : $1 \mathrm{~d}$ post-TBI $+1 \mathrm{mM} P Q Q$ group; $3 \mathrm{~L}: 3 \mathrm{~d}$ post-TBI + $1 \mathrm{mM}$ PQQ group; $5 \mathrm{~L}: 5 \mathrm{~d}$ post-TBI $+1 \mathrm{mM}$ PQQ group; $7 \mathrm{~L}: 7 \mathrm{~d}$ post-TBI $+1 \mathrm{mM}$ PQQ group; $1 \mathrm{H}: 1 \mathrm{~d}$ post-TBI $+2 \mathrm{mM}$ PQQ group; $3 \mathrm{H}$ : $3 \mathrm{~d}$ post-TBI $+2 \mathrm{mM}$ PQQ group; $5 \mathrm{H}$ : 5d post-TBI $+2 \mathrm{mM}$ PQQ group; $7 \mathrm{H}: 7 \mathrm{~d}$ post-TBI $+2 \mathrm{mM}$ PQQ group.
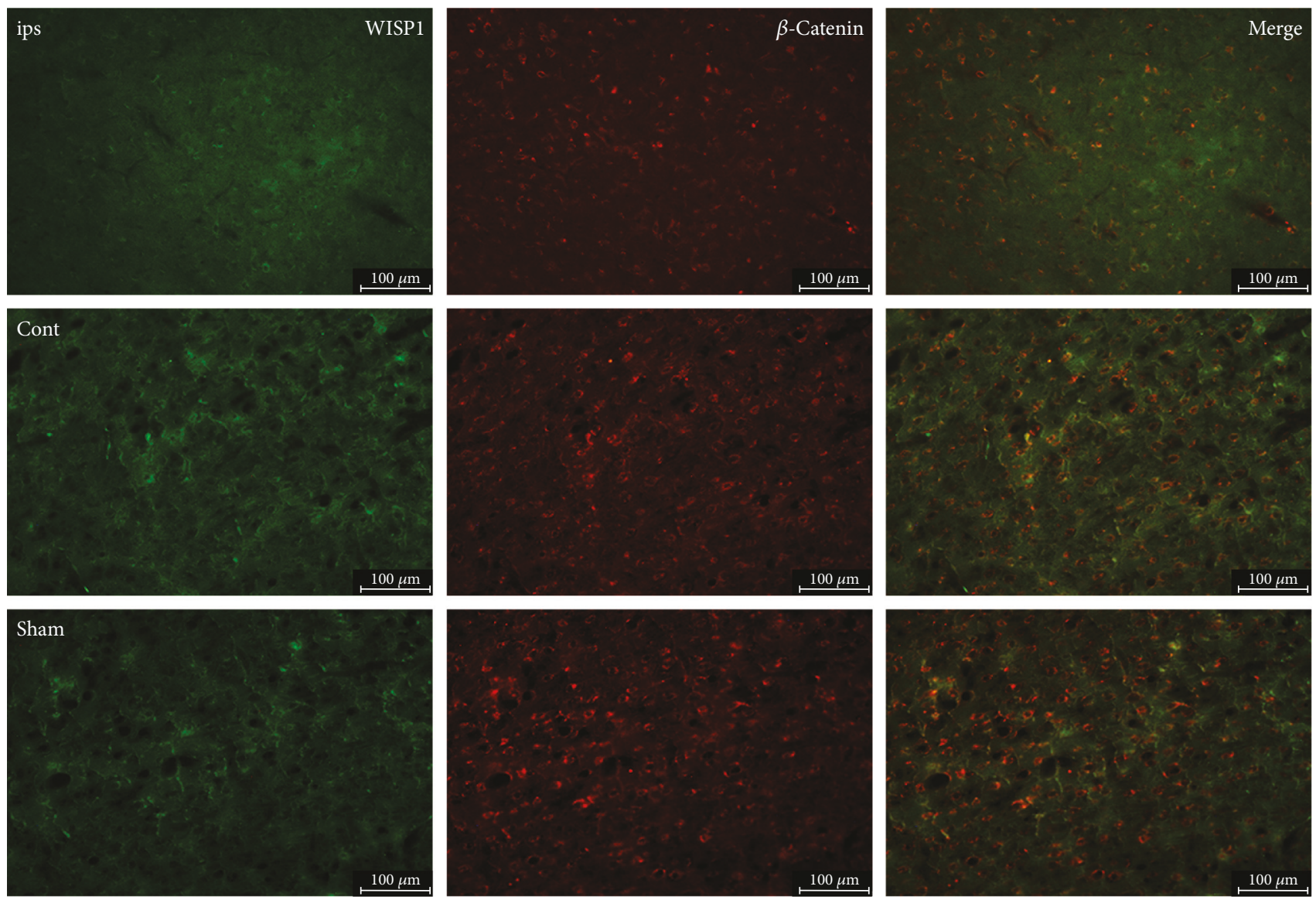

FIGURE 8: Double-labeling immunofluorescence of WISP1 and $\beta$-catenin at $3 \mathrm{~d}$ after TBI. Green: WISP1; red: $\beta$-catenin; cont: the control of ipsilateral $3 \mathrm{~d}$ post-TBI group; ips: ipsilateral $3 \mathrm{~d}$ post-TBI group; sham: sham group; bar $=100 \mu \mathrm{m}$.

in the gastrointestinal tract [25]. In the present study, WISP1 mRNA expression was detected by qRT-PCR after brain injury. Compared with the sham group, WISP1
mRNA expression reached to the minimum at $3 \mathrm{~d}$ and then recovered at $5 \mathrm{~d}$ after TBI. Meanwhile, the expression of WISP1 mRNA increased with $1 \mathrm{mM}$ or $2 \mathrm{mM}$ PQQ at 


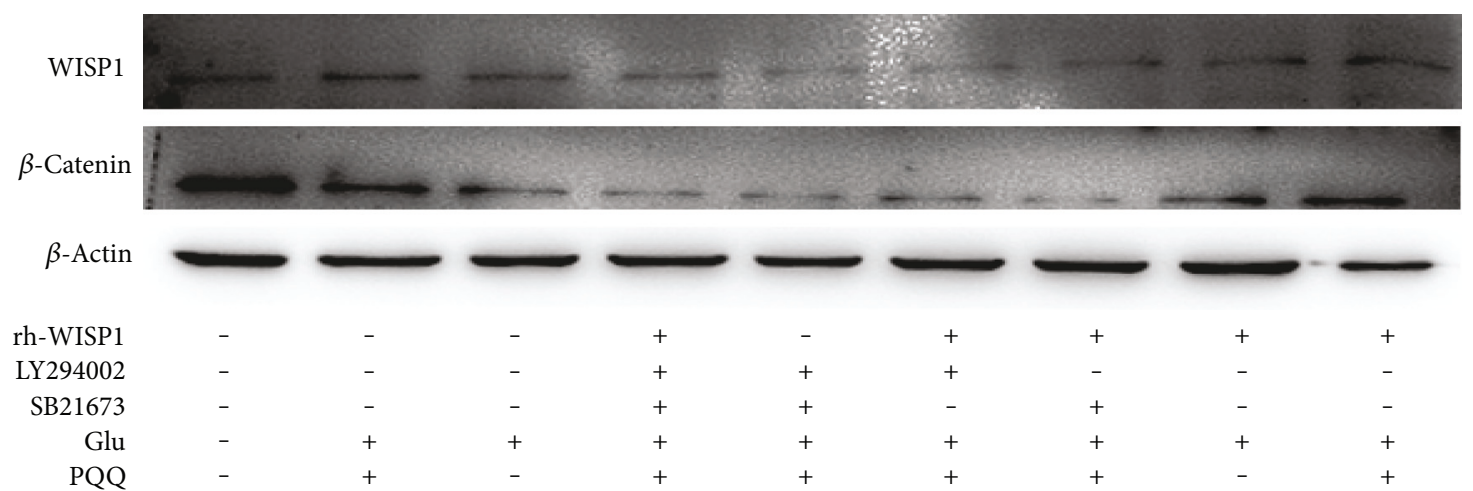

(a)

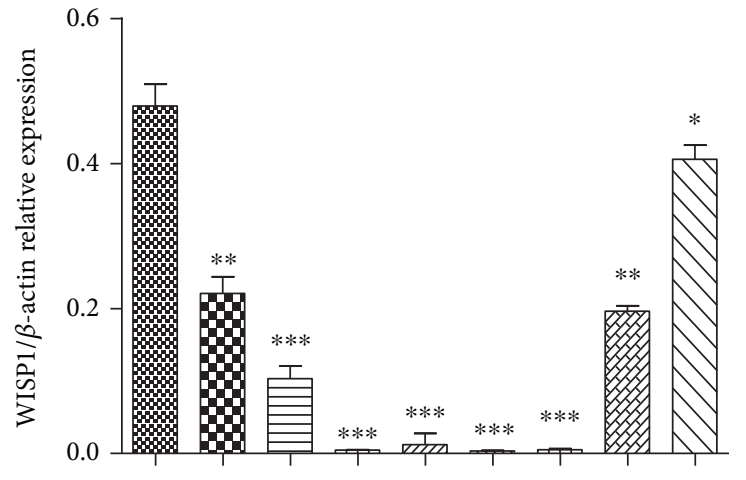

(b)

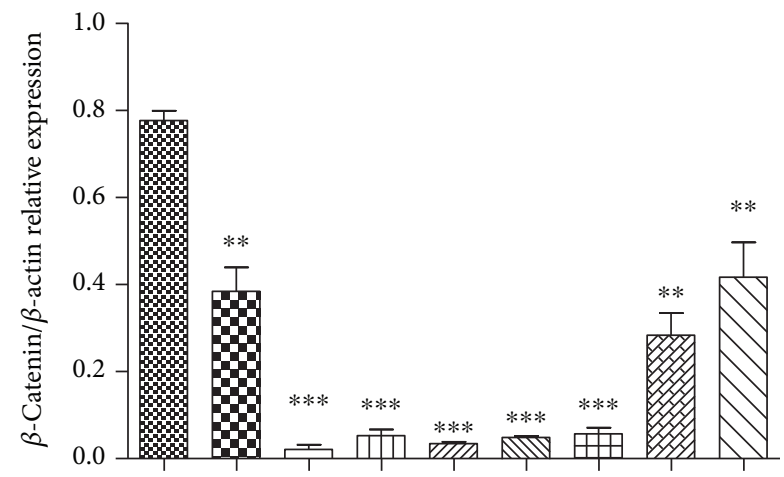

(c)

Figure 9: WISP1 and $\beta$-catenin protein expression after blocking PI3K/GSK-3 $\beta$ signaling pathway $\left({ }^{*} P<0.05,{ }^{* *} P<0.01,{ }^{* * *} P<0.001\right.$ versus sham).
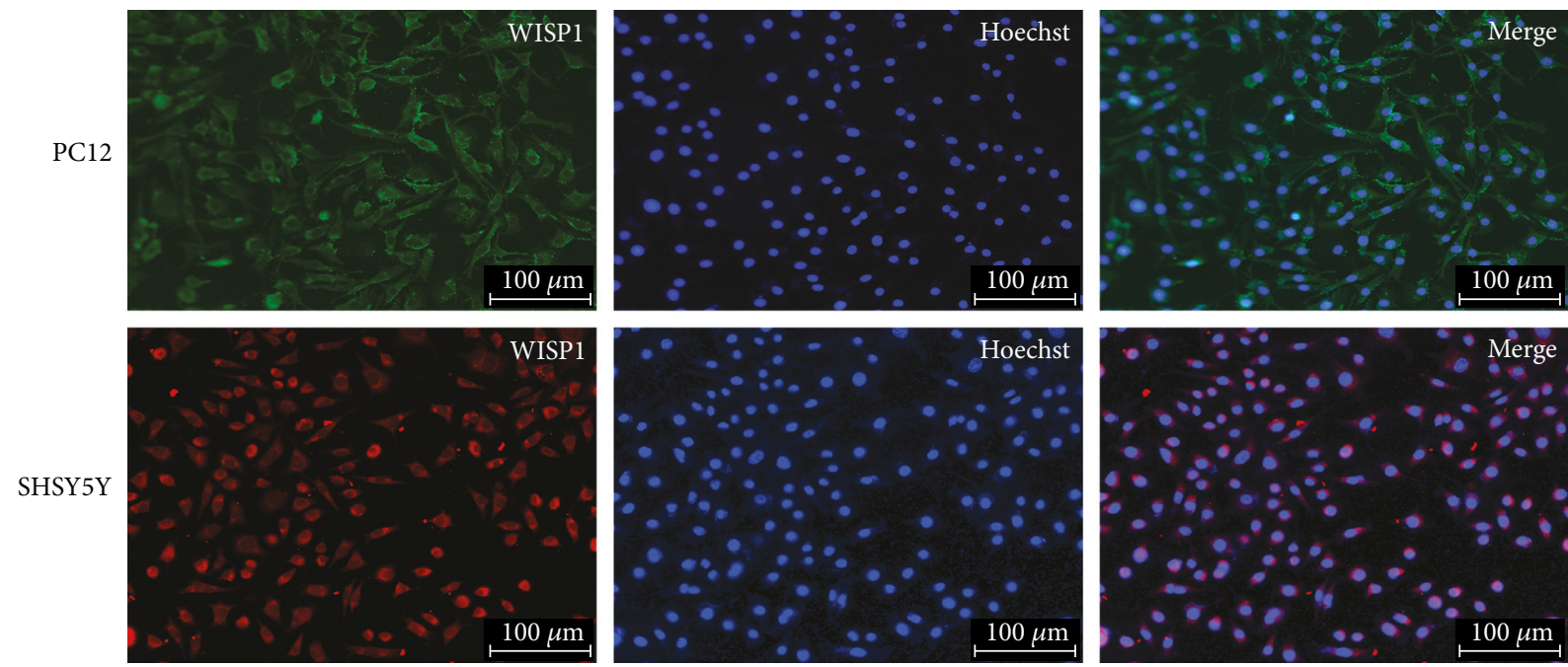

FIgURE 10: Immunofluorescence of WISP1 in SHSY5Y with PC12 cells. Red or green: WISP1; blue: Hoechst; bar $=100 \mu \mathrm{m}$.

different time post-TBI, but the effect of $1 \mathrm{mM}$ PQQ was obvious to the $2 \mathrm{mM}$ PQQ, which might be the concentration of $1 \mathrm{mM}$ PQQ in animals that can reach the optimum serum concentration in TBI.

Astrocyte activation is a common reaction in the central nervous system under many pathophysiological situations, which assume astrocyte cell hypertrophy, swelling, protuberance extension, and glial fibrillary acidic protein expression increase [26, 27]. Astrocytes began to activate after TBI and may even cause several neurodegenerative diseases. In the paper, double-labeling immunofluorescence was performed to detect the cell type that WISP1 located in the brain. Results indicated WISP1 located mainly in the neuron of the brain through the colocalization of 

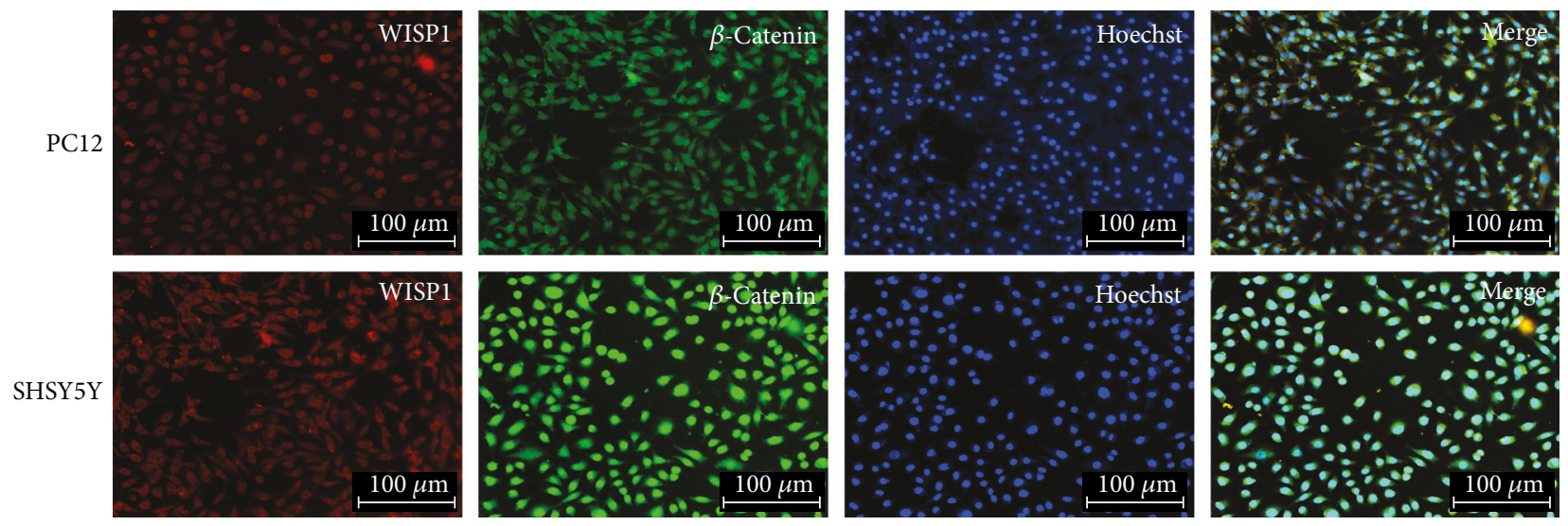

Figure 11: Double-labeling immunofluorescence of WISP1 in SHSY5Y with PC12 cells. Red: WISP1; green: $\beta$-catenin; blue: Hoechst; bar $=100 \mu \mathrm{m}$.

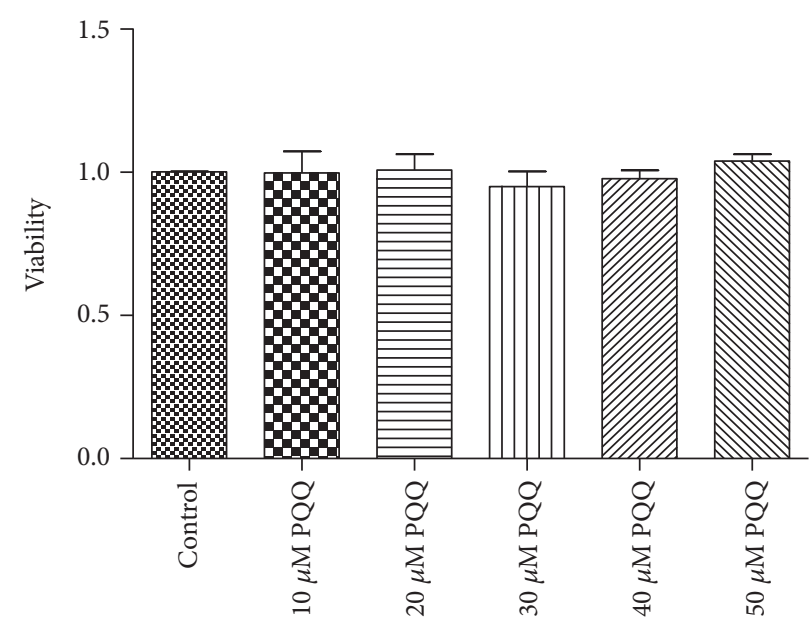

(a)

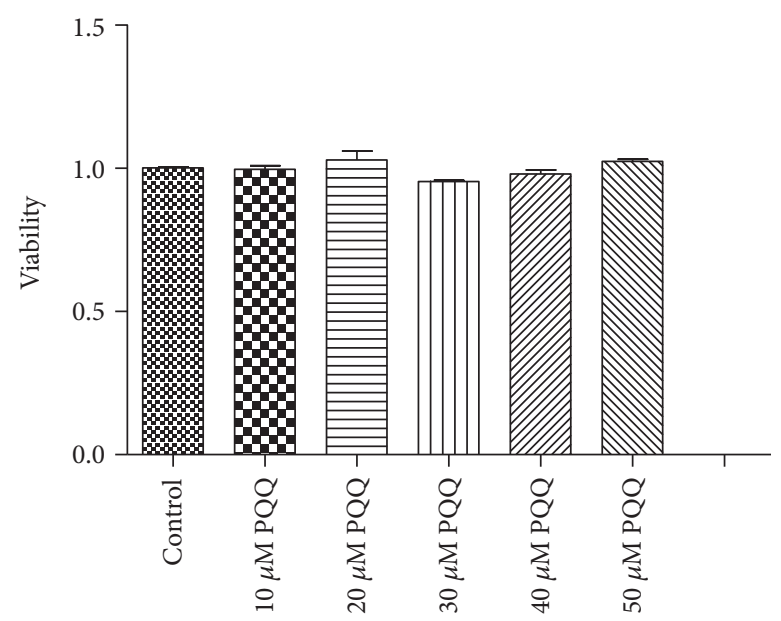

(b)

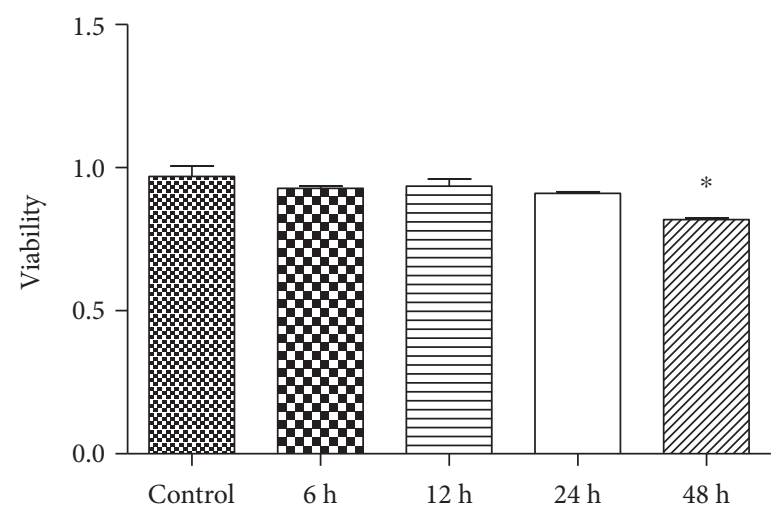

(d)

FIgUre 12: The effect of PQQ on the viability of PC12 and SHSY5Y cells. (a) Control: PC12 cells without PQQ; (b) control: SHSY5Y cells without PQQ; (c) control: PC12 cells without PQQ, ${ }^{*} P<0.05$ versus control; (d) control: SHSY5Y cells without PQQ, ${ }^{*} P<0.05$ versus control.

WISP1 with astrocyte marker GFAP, neuronal marker NeuN, and microglia marker Iba1, respectively.

After traumatic brain injury, there would be different levels of autophagy. Autophagy has three different categories termed microautophagy, macroautophagy, and chaperonemediated autophagy [28]. Autophagy is a eukaryotic cell metabolic process, autophagy with disease-linked, is gradually increasing in the recent years. Autophagy is involved in 

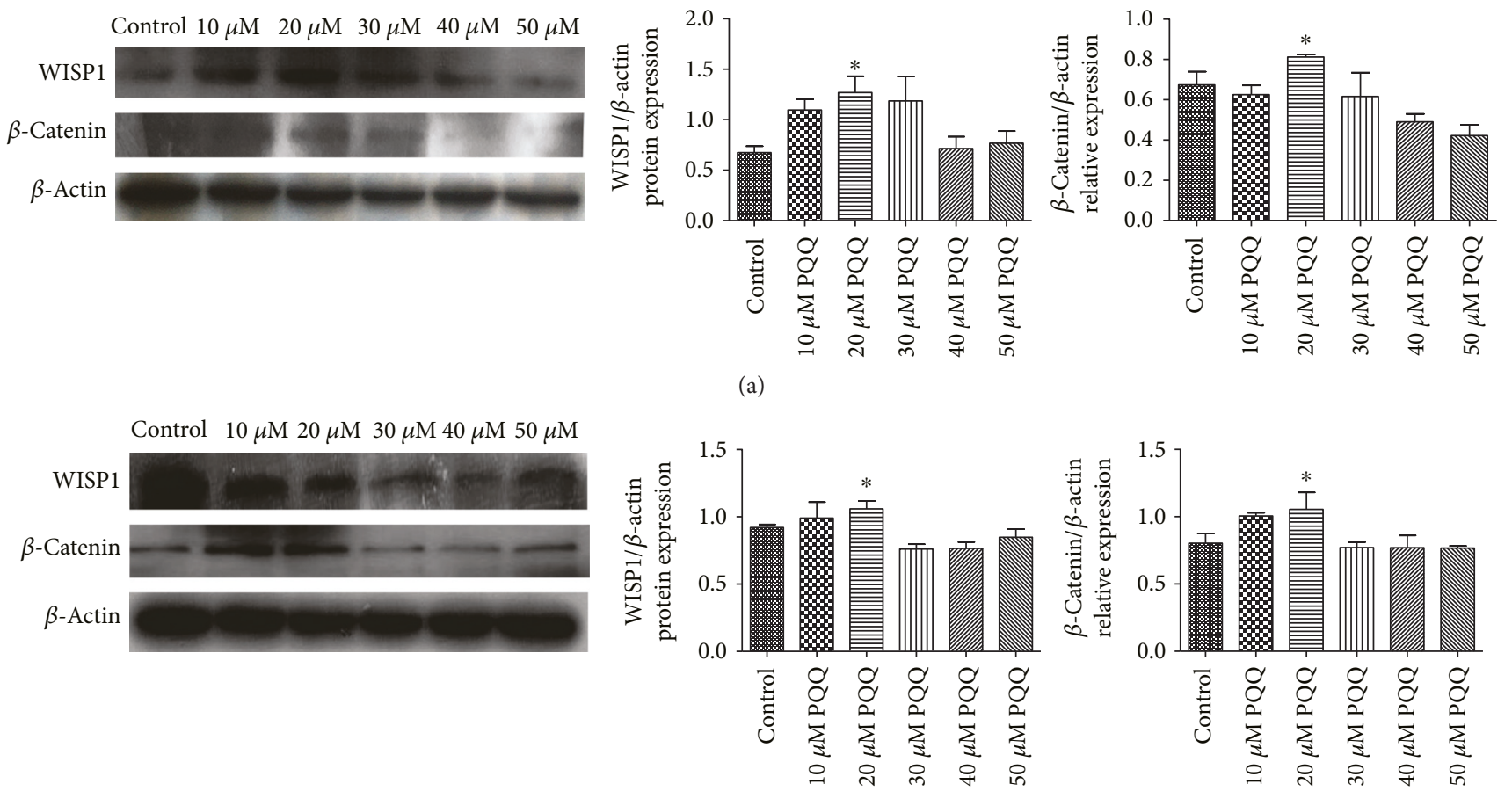

(b)

FIgURE 13: WISP1 and $\beta$-catenin protein expressions in PC12 cells and SHSY5Y cells with the treatment of different concentrations of PQQ. (a) Control: PC12 cells without PQQ; 10, 20, 30, 40, and $50 \mu \mathrm{M}$ : different concentrations of PQQ for $24 \mathrm{~h}$; (b) control: SHSY5Y cells without PQQ $\left({ }^{*} P<0.05\right)$.
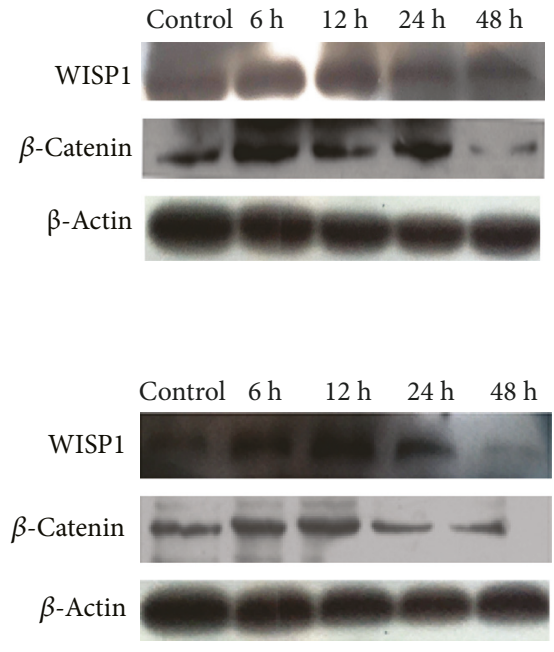

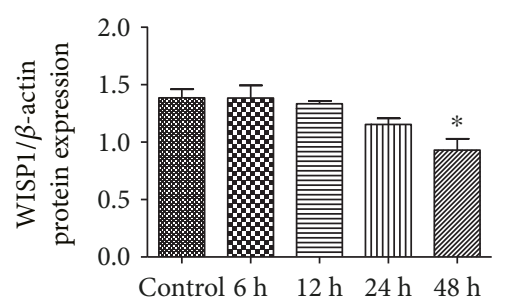

(a)

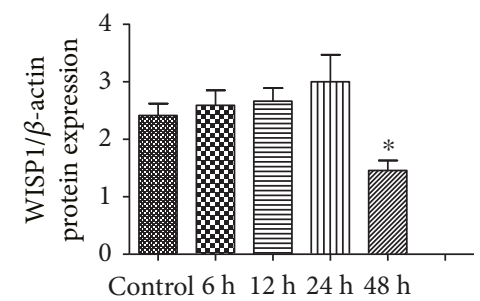

(b)
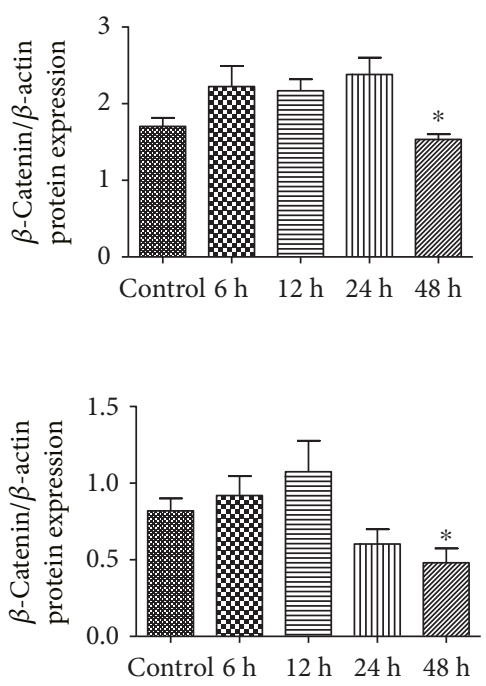

FIGURE 14: WISP1, $\beta$-catenin protein expression in PC12 cells, and SHSY5Y cells with the treatment of $50 \mu M$ PQQ at different time. (a) Control: PC12 cells without PQQ; $6 \mathrm{~h}, 12 \mathrm{~h}, 24 \mathrm{~h}$, and $48 \mathrm{~h}$ : different time points; (b) control: SHSY5Y cells without PQQ $\left({ }^{*} P<0.05\right)$.

pathogenesis of neuronal injury and death including mitochondrial damage, activating inflammation, oxidative free radicals, and caspase activation [29]. Apart from cell death which was caused by TBI, autophagic cell death and apoptosis occupy a considerable proportion, autophagy protects damaged cells and also exacerbates cell damage, which mainly depend on the role of autophagy after injury and stage. Autophagy is involved in regulation of cell survival after death in traumatic brain injury, and as a result, autophagy is important to brain injury and nerve injury and repair [30]. Double immunofluorescence of WISP1 and autophagy marker LC3 showed that WISP1 and LC3 had a lot of colocalization at $3 \mathrm{~d}$ post-TBI. After treatment with $1 \mathrm{mM}$ PQQ, WISP1-positive signals rose obviously; LC3-positive signals declined markedly in the ipsilateral brain. All these data demonstrated that PQQ may have a protective role on autophagy. 

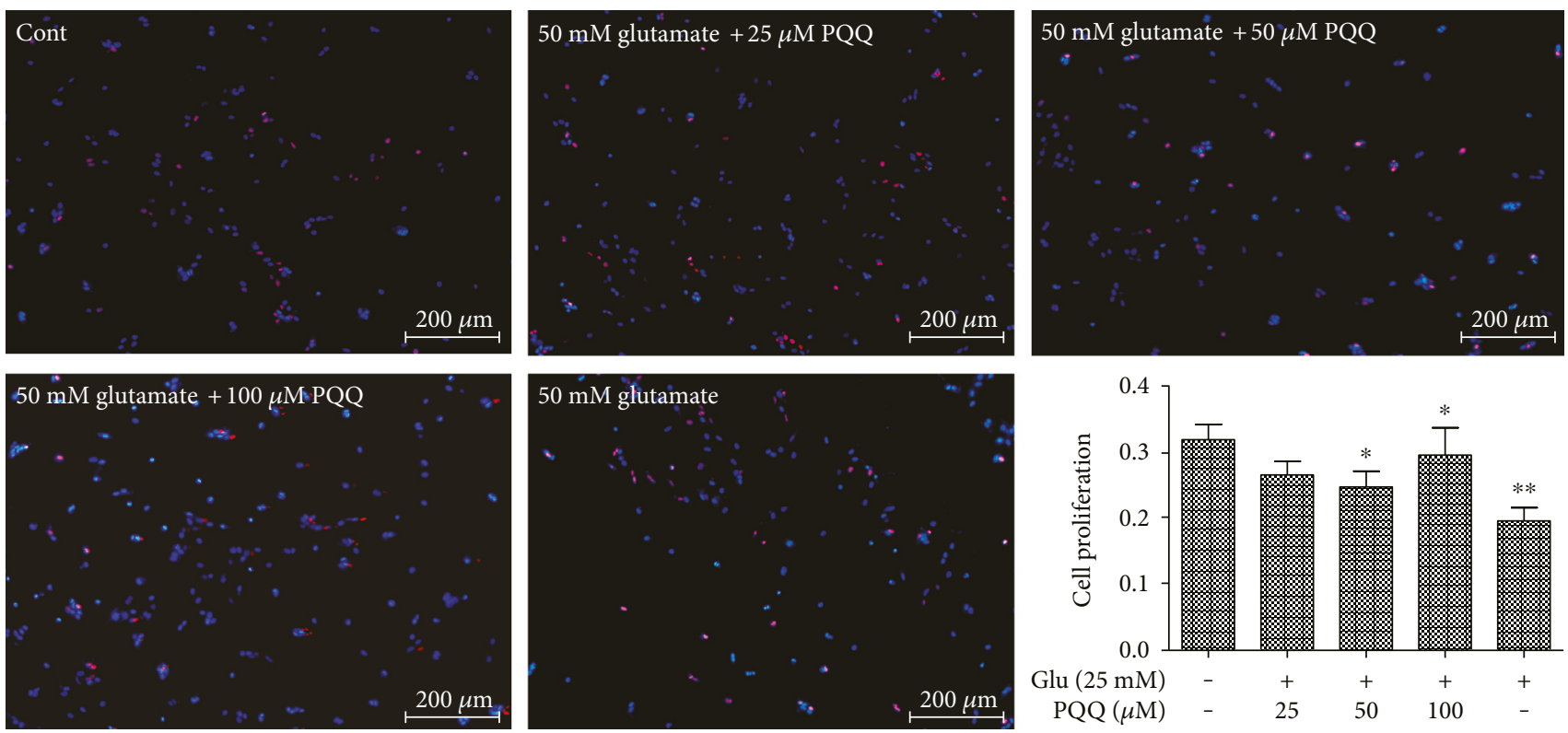

FIgure 15: The proliferation of astrocytes with glutamate and PQQ $\left({ }^{*} P<0.05,{ }^{* *} P<0.01\right)$.
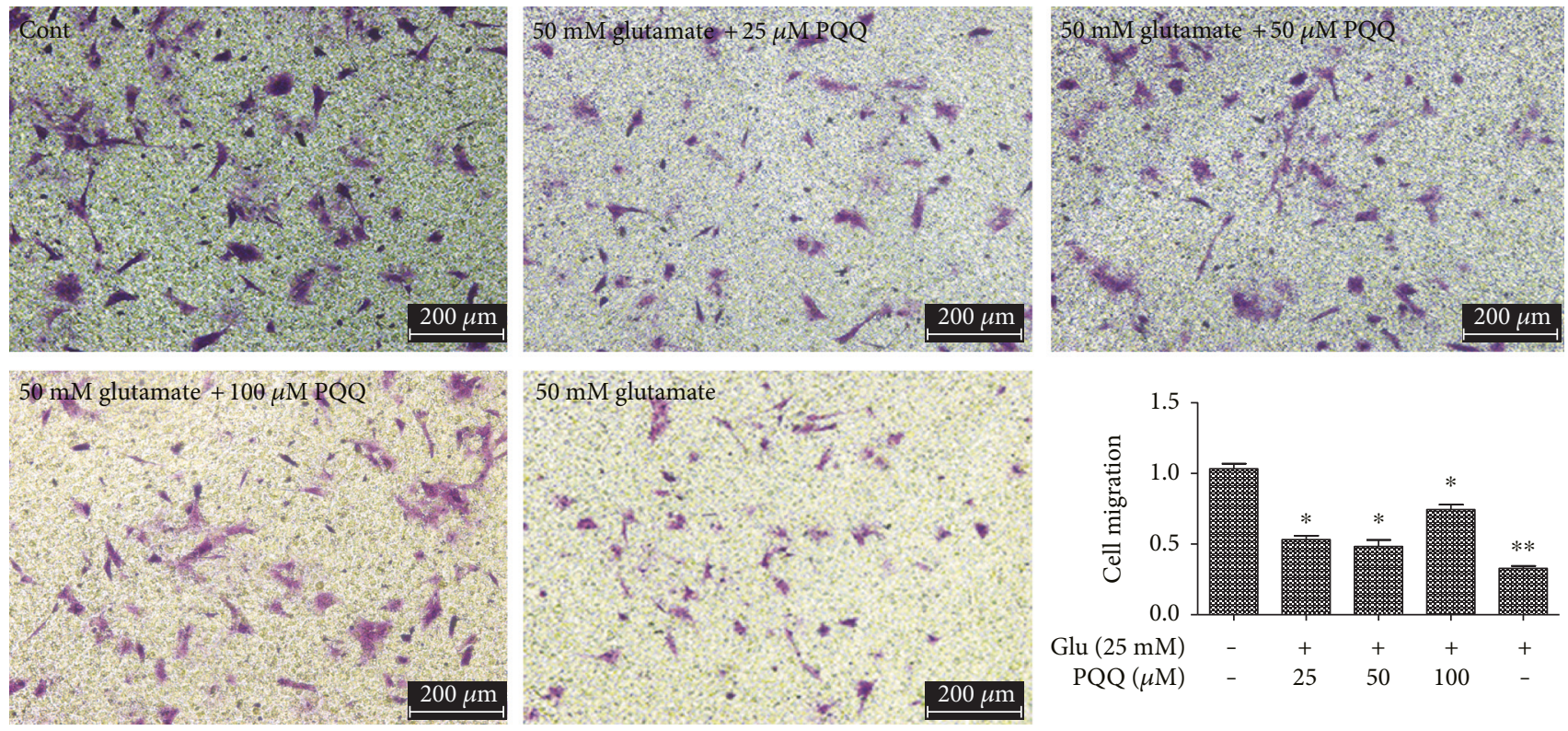

Figure 16: The migration of astrocytes after glutamate and PQQ $\left({ }^{*} P<0.05,{ }^{* *} P<0.01\right)$.

In addition, apoptosis is believed to be a significant contributor to the pathogenesis of a variety of disorders after TBI. For example, in the brains of patients with Alzheimer's disease, apoptotic DNA fragmentation [31] and caspase activation have been observed [32]. Caspase-3 activation is relevant to the apoptosis of neurons after various types of damage. In this study, double-labeling immunofluorescence showed that WISP1 colocalizated with cleaved caspase partly. Cleaved caspase-3 expression was obviously upregulated in the ipsilateral brain after $3 \mathrm{~d}$ post-TBI. After treatment with $1 \mathrm{mM}$ PQQ, cleaved caspase-3-positive signals declined obviously, which reminded that WISP1 might not be involved directly in the process of apoptosis.

WISP1 and $\beta$-catenin act as new targets investigated in recent years, which can promote tissues proliferation as well as various cell repair. In regard to the canonical pathways of Wnt1 [33], WISP1 can block phosphorylation of $\beta$-catenin in neurons that may be mediated through the inhibition of GSK-3 $\beta$ which prevent $\beta$-catenin phosphorylation [33]. WISP1 also can block GSK-3 $\beta$ activity in other cell systems such as cardiac cells $[12,34]$. In neurons, WISP1 through a PI3K-mediated pathway promotes the nucleus expression of 


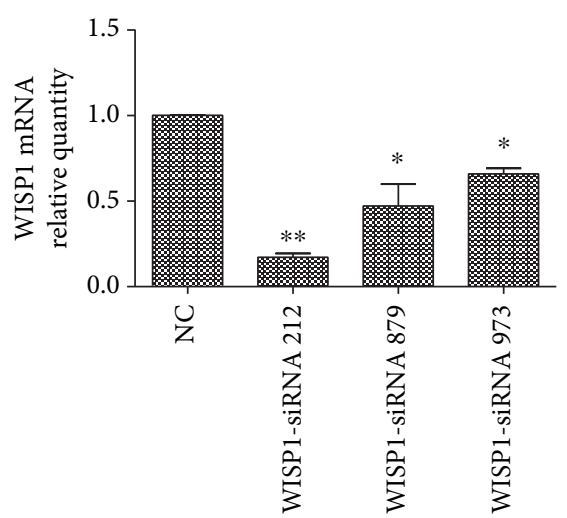

(a)

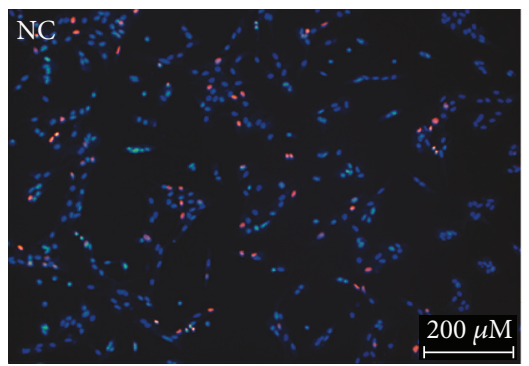

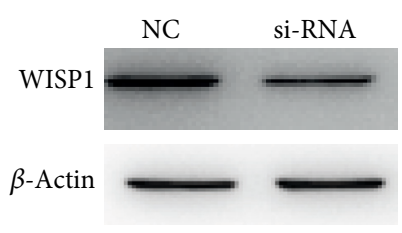

祭 (b)

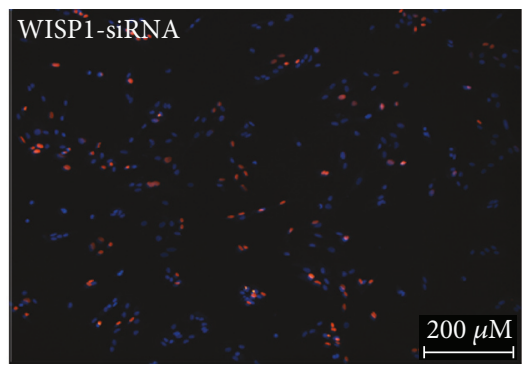

(d)
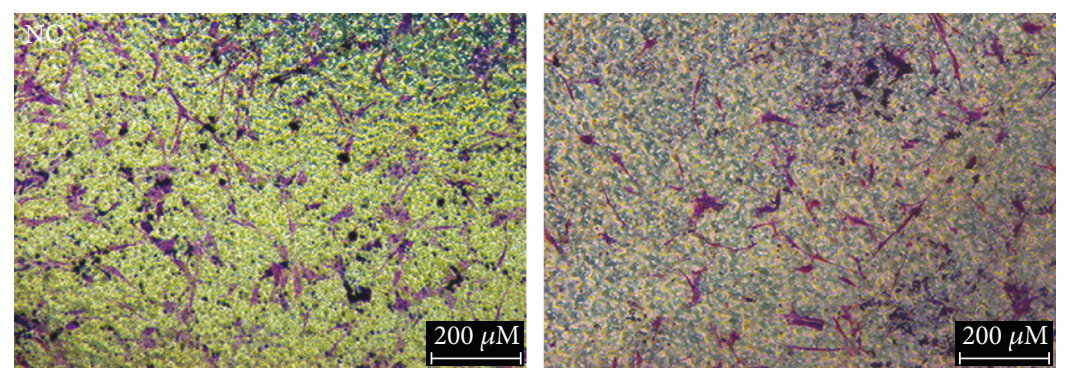

(f)

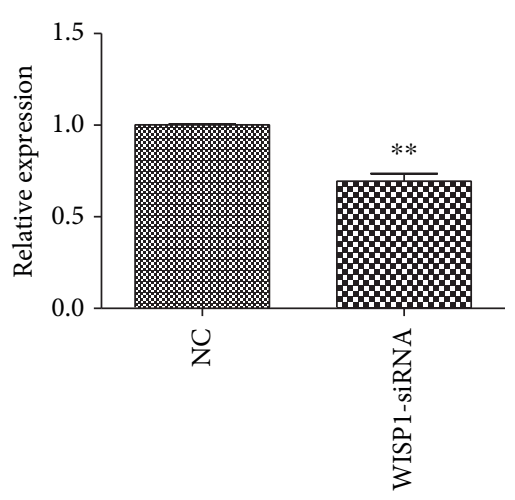

(c)

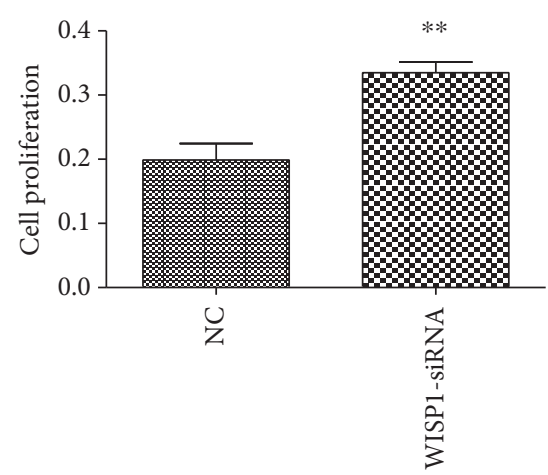

(e)

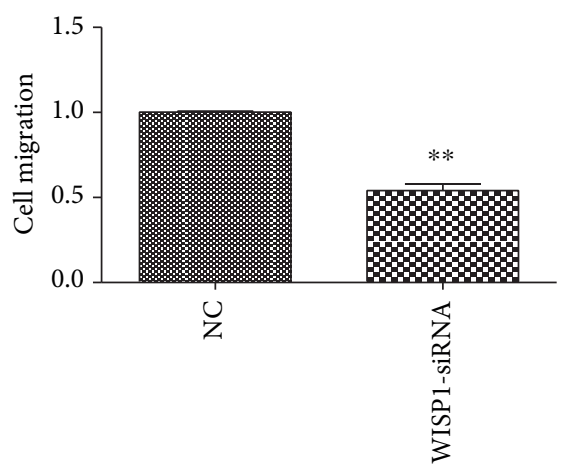

(g)

FIGURE 17: The proliferation and migration of astrocytes after transfected by WISP1 si-RNA. NC: negative control group ( $P<0.05$ ). (a) qRTPCR showed that the expression of WISP1 in astrocytes transfected with WISP1 si-RNA. (b) Western blot showed that WISP1 si-RNA could decreased the expression of WISP1 protein. (c) The statistic graph of (b). (d) Proliferation of astrocytes transfected with WISP1 si-RNA compared with the normal group. (e) The statistic graph of (d) $\left({ }^{* *} P<0.01\right)$. (f) The migration of astrocytes transfected with WISP1 si-RNA compared with the normal group. (g) The statistic graph of (f) $\left(^{* *} P<0.01\right)$.

$\beta$-catenin [4]. In addition, WISP1 expression is governed by $\beta$-catenin activity and WISP1 regulates its own expression through the ability of WISP1 to control $\beta$-catenin phosphorylation and nuclear translocation [4]. Western blot showed that the protein expression of WISP 1 and $\beta$-catenin minimized at $3 \mathrm{~d}$ and rose again at $5 \mathrm{~d}$ after TBI compared with the sham group. Meanwhile, the treatment with $1 \mathrm{mM}$ or $2 \mathrm{mM}$ PQQ increased the protein expression of WISP1 and $\beta$-catenin correspondingly. All these results demonstrated that WISP1 may modulate the protein expression of $\beta$-catenin.

PQQ, also known as methoxatin, has been detected in a wide variety of foods and other sources. PQQ, as an important antioxidant and nutrient, has also begun to focus on nutriology and pharmacology. PQQ belongs to vitamin B 
[21]. PQQ has many other pharmacological effects, including anti-inflammatory, hepatoprotective, heart protection, and antioxidizing effect $[22,35,36]$. PQQ has a neuroprotective function and a very good effect on the epilepsy model by PI3K/AKT signaling pathway [37]. Although the role of PQQ as a vitamin in animal or human nutrition is controversial, accumulating evidence suggest that PQQ plays important roles on cell protection. In the experiment, we used different concentrations of PQQ to treat SHSY5Y or PC12 cells; results showed that PQQ had no toxicity on the cell lines. Similarly, PQQ had no significant effect on the animal without TBI. In subsequent experiments, in addition, PQQ may protect cells through influencing the expression of WISP1.

\section{Conflicts of Interest}

The authors declare that they have no conflicts of interest.

\section{Acknowledgments}

This work was supported by the National Natural Scientific Foundation of China (31370803), Application Study Program of Nantong City (BK2013004), Early Pre-research Program of Nantong University (10ZY013), and Doctoral Program of Nantong University (12B035).

\section{References}

[1] A. Feeney, C. D. Johnston, R. Govender, J. O’Mahony, A. Coffey, and R. D. Sleator, "Analysis of the role of the Cronobacter sakazakii ProP homologues in osmotolerance," Gut Pathogens, vol. 6, p. 15, 2014.

[2] S. Wang, Z. Zhong Chong, Y. Chen Shang, and K. Maiese, "WISP1 neuroprotection requires FoxO3a post-translational modulation with autoregulatory control of SIRT1," Current Neurovascular Research, vol. 10, no. 1, pp. 54-69, 2013.

[3] K. Venkatachalam, B. Venkatesan, A. J. Valente et al., "WISP1, a pro-mitogenic, pro-survival factor, mediates tumor necrosis factor-alpha (TNF-alpha)-stimulated cardiac fibroblast proliferation but inhibits TNF-alpha-induced cardiomyocyte death," The Journal of Biological Chemistry, vol. 284, no. 21, pp. 14414-14427, 2009.

[4] S. Wang, Z. Zhong Chong, Y. Chen Shang, and K. Maiese, "WISP1 (CCN4) autoregulates its expression and nuclear trafficking of beta-catenin during oxidant stress with limited effects upon neuronal autophagy," Current Neurovascular Research, vol. 9, no. 2, pp. 91-101, 2012.

[5] D. Pennica, T. A. Swanson, J. W. Welsh et al., "WISP genes are members of the connective tissue growth factor family that are up-regulated in Wnt1-transformed cells and aberrantly expressed in human colon tumors," Proceedings of the National Academy of Sciences of the United States of America, vol. 95, no. 25, pp. 14717-14722, 1998.

[6] T. Doerks, R. R. Copley, J. Schultz, C. P. Ponting, and P. Bork, "Systematic identification of novel protein domain families associated with nuclear functions," Genome Research, vol. 12, no. 1, pp. 47-56, 2002.

[7] J. T. Colston, S. D. de la Rosa, M. Koehler et al., "Wnt1induced secreted protein-1 is a prohypertrophic and profibrotic growth factor," American Journal of Physiology Heart and
Circulatory Physiology, vol. 293, no. 3, pp. H1839-H1846, 2007.

[8] C. H. Hou, Y. C. Chiang, Y. C. Fong, and C. H. Tang, "WISP-1 increases MMP-2 expression and cell motility in human chondrosarcoma cells," Biochemical Pharmacology, vol. 81, no. 11, pp. 1286-1295, 2011.

[9] R. L. Heise, V. Stober, C. Cheluvaraju, J. W. Hollingsworth, and S. Garantziotis, "Mechanical stretch induces epithelialmesenchymal transition in alveolar epithelia via hyaluronan activation of innate immunity," The Journal of Biological Chemistry, vol. 286, no. 20, pp. 17435-17444, 2011.

[10] D. M. French, R. J. Kaul, A. L. D'Souza et al., "WISP-1 is an osteoblastic regulator expressed during skeletal development and fracture repair," The American Journal of Pathology, vol. 165, no. 3, pp. 855-867, 2004.

[11] H. Kohara and Y. Tabata, "Enhancement of ectopic osteoid formation following the dual release of bone morphogenetic protein 2 and Wnt1 inducible signaling pathway protein 1 from gelatin sponges," Biomaterials, vol. 32 , no. 24 , pp. $5726-$ 5732, 2011.

[12] S. Wang, Z. Zhong Chong, Y. Chen Shang, and K. Maiese, "Wnt1 inducible signaling pathway protein 1 (WISP1) blocks neurodegeneration through phosphoinositide 3 kinase/AKT1 and apoptotic mitochondrial signaling involving bad, Bax, Bim, and Bcl-xL," Current Neurovascular Research, vol. 9, no. 1, pp. 20-31, 2012.

[13] C. Nusslein-Volhard and E. Wieschaus, "Mutations affecting segment number and polarity in Drosophila," Nature, vol. 287, no. 5785, pp. 795-801, 1980.

[14] P. D. McCrea, C. W. Turck, and B. Gumbiner, "A homolog of the armadillo protein in Drosophila (plakoglobin) associated with E-cadherin," Science, vol. 254, no. 5036, pp. 13591361, 1991.

[15] W. I. Weis and W. J. Nelson, "Re-solving the cadherin-cateninactin conundrum," The Journal of Biological Chemistry, vol. 281, no. 47, pp. 35593-35597, 2006.

[16] A. Klaus and W. Birchmeier, "Wnt1 signalling and its impact on development and cancer," Nature Reviews Cancer, vol. 8, no. 5, pp. 387-398, 2008.

[17] O. M. Lucero, D. W. Dawson, R. T. Moon, and A. J. Chien, “A re-evaluation of the "oncogenic" nature of Wnt1/beta-catenin signaling in melanoma and other cancers," Current Oncology Reports, vol. 12, no. 5, pp. 314-318, 2010.

[18] L. Xu, R. B. Corcoran, J. W. Welsh, D. Pennica, and A. J. Levine, "WISP-1 is a Wnt1-1- and beta-catenin-responsive oncogene," Genes \& Development, vol. 14, no. 5, pp. 585$595,2000$.

[19] T. M. Nguyen, I. V. Subramanian, X. Xiao et al., "Endostatin induces autophagy in endothelial cells by modulating Beclin 1 and beta-catenin levels," Journal of Cellular and Molecular Medicine, vol. 13, no. 9B, pp. 3687-3698, 2009.

[20] Y. Wang, L. Ding, X. Wang et al., "Pterostilbene simultaneously induces apoptosis, cell cycle arrest and cyto-protective autophagy in breast cancer cells," American Journal of Translational Research, vol. 4, no. 1, pp. 44-51, 2012.

[21] T. Kasahara and T. Kato, "Nutritional biochemistry: a new redox-cofactor vitamin for mammals," Nature, vol. 422, no. 6934, p. 832, 2003.

[22] B. Q. Zhu, H. Z. Zhou, J. R. Teerlink, and J. S. Karliner, "Pyrroloquinoline quinone (PQQ) decreases myocardial infarct size and improves cardiac function in rat models of 
ischemia and ischemia/reperfusion," Cardiovascular Drugs and Therapy, vol. 18, no. 6, pp. 421-431, 2004.

[23] J. Killgore, C. Smidt, L. Duich, N. Romero-Chapman, and D. Tinker, "Nutritional importance of pyrroloquinoline quinone," Science, vol. 245, no. 4920, pp. 850-852, 1989.

[24] S. R. Datta, A. Brunet, and M. E. Greenberg, "Cellular survival: a play in three AKTs," Genes \& Development, vol. 13, no. 22, pp. 2905-2927, 1999.

[25] M. Halperin-Sheinfeld, A. Gertler, E. Okun, B. Sredni, and H. Y. Cohen, "The tellurium compound, AS101, increases SIRT1 level and activity and prevents type 2 diabetes," Aging (Albany NY), vol. 4, no. 6, pp. 436-447, 2012.

[26] I. L. Cabezas, A. Herrera Batista, and G. Pentón Rol, “The role of glial cells in Alzheimer disease: potential therapeutic implications," Neurología, vol. 29, no. 5, pp. 305-309, 2014.

[27] J. K. Young, "Anatomical relationship between specialized astrocytes and leptin-sensitive neurones," Journal of Anatomy, vol. 201, no. 1, pp. 85-90, 2002.

[28] E. Yamada and R. Singh, "Mapping autophagy on to your metabolic radar," Diabetes, vol. 61, no. 2, pp. 272-280, 2012.

[29] R. Raghupathi, "Cell death mechanisms following traumatic brain injury," Brain Pathology, vol. 14, no. 2, pp. 215-222, 2004.

[30] D. C. Rubinsztein, M. DiFiglia, N. Heintz et al., "Autophagy and its possible roles in nervous system diseases, damage and repair," Autophagy, vol. 1, no. 1, pp. 11-22, 2005.

[31] M. Broe, C. E. Shepherd, E. A. Milward, and G. M. Halliday, "Relationship between DNA fragmentation, morphological changes and neuronal loss in Alzheimer's disease and dementia with Lewy bodies," Acta Neuropathologica, vol. 101, no. 6, pp. 616-624, 2001.

[32] N. Louneva, J. W. Cohen, L. Y. Han et al., "Caspase-3 is enriched in postsynaptic densities and increased in Alzheimer's disease," The American Journal of Pathology, vol. 173, no. 5, pp. 1488-1495, 2008.

[33] K. Maiese, F. Li, Z. Z. Chong, and Y. C. Shang, "The Wnt1 signaling pathway: aging gracefully as a protectionist?" Pharmacology \& Therapeutics, vol. 118, no. 1, pp. 58-81, 2008.

[34] B. Venkatesan, S. D. Prabhu, K. Venkatachalam et al., "Wnt1 inducible signaling pathway protein-1 activates diverse cell survival pathways and blocks doxorubicin-induced cardiomyocyte death," Cellular Signalling, vol. 22, no. 5, pp. 809$820,2010$.

[35] K. He, H. Nukada, T. Urakami, and M. P. Murphy, “Antioxidant and pro-oxidant properties of pyrroloquinoline quinone (PQQ): implications for its function in biological systems," Biochemical Pharmacology, vol. 65, no. 1, pp. 67-74, 2003.

[36] Y. Zhang, P. J. Feustel, and H. K. Kimelberg, "Neuroprotection by pyrroloquinoline quinone (PQQ) in reversible middle cerebral artery occlusion in the adult rat," Brain Research, vol. 1094, no. 1, pp. 200-206, 2006.

[37] R. M. Sanchez, C. Wang, G. Gardner et al., "Novel role for the NMDA receptor redox modulatory site in the pathophysiology of seizures," The Journal of Neuroscience, vol. 20, no. 6, pp. 2409-2417, 2000. 

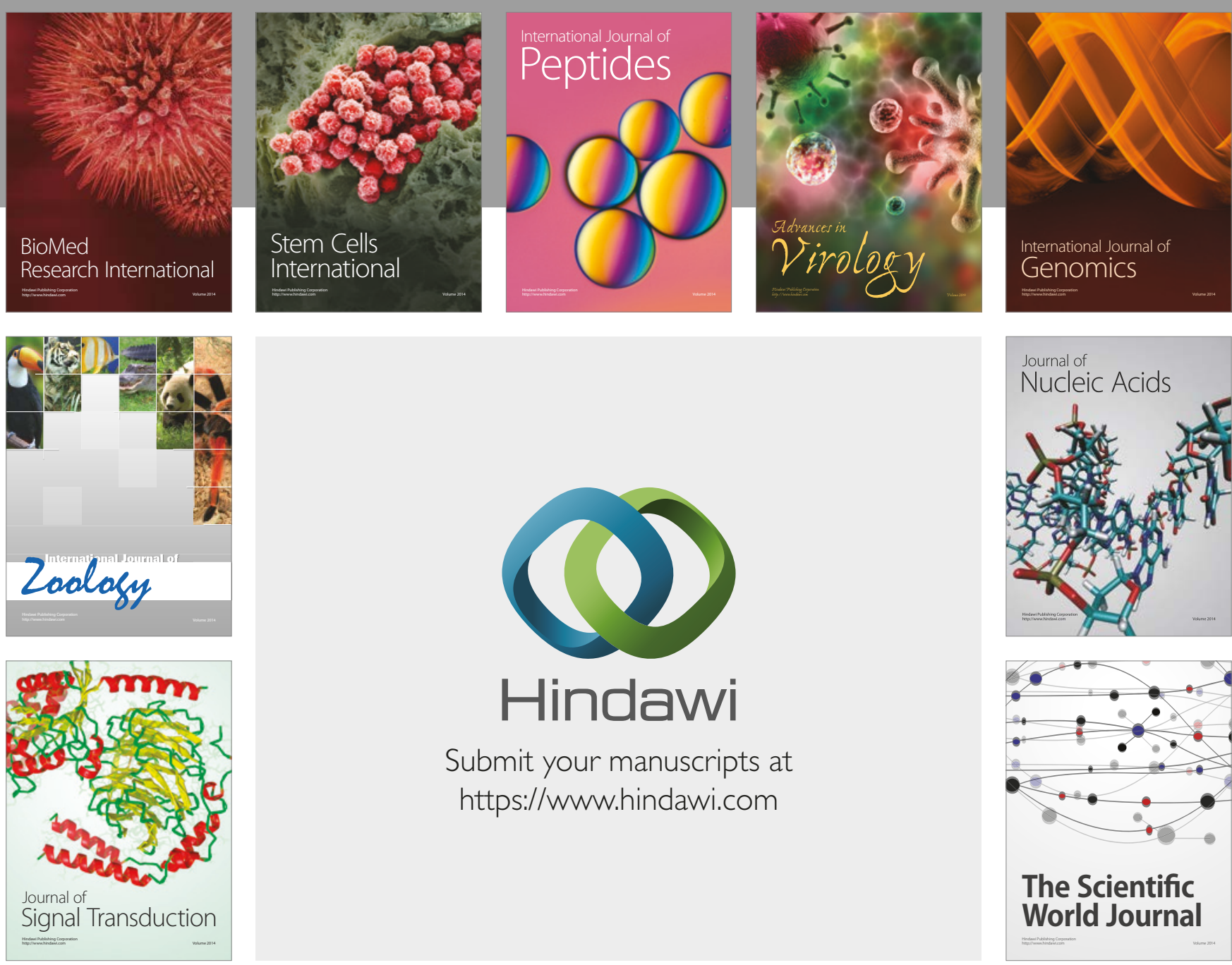

Submit your manuscripts at

https://www.hindawi.com
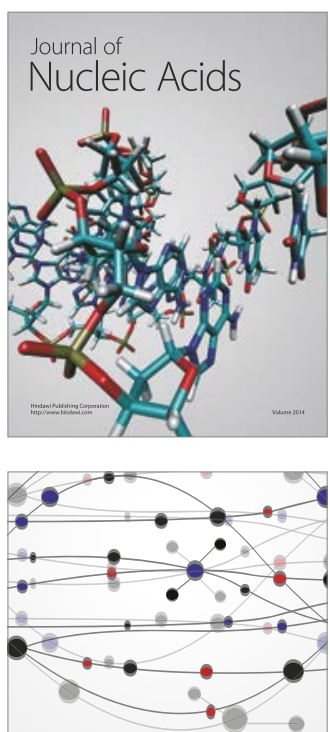

The Scientific World Journal

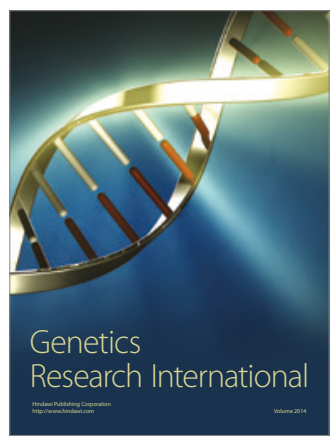

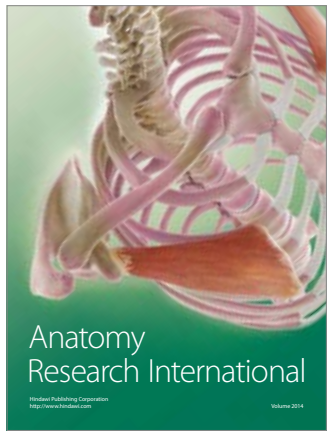

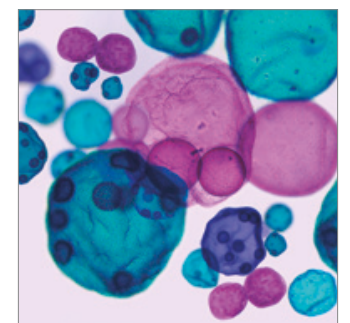

International Journal of Microbiology
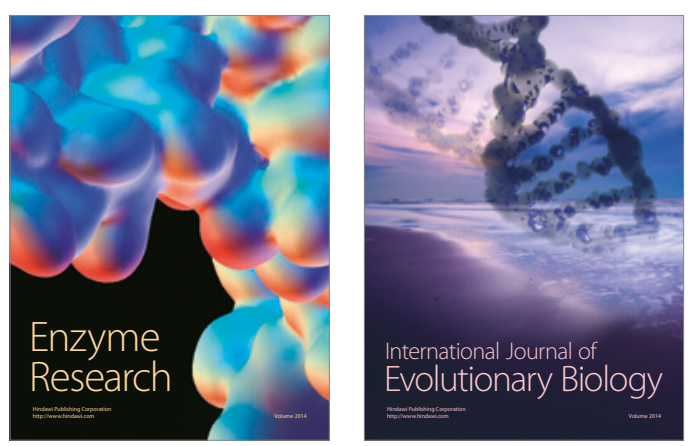
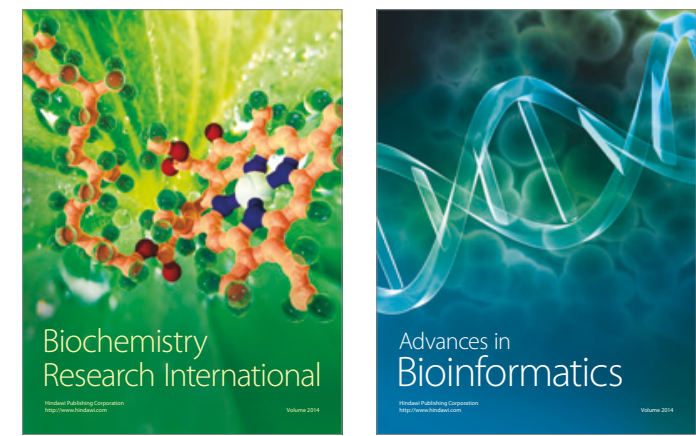

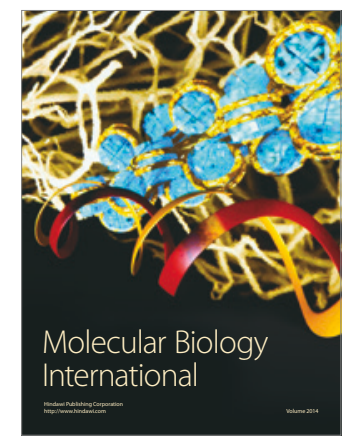

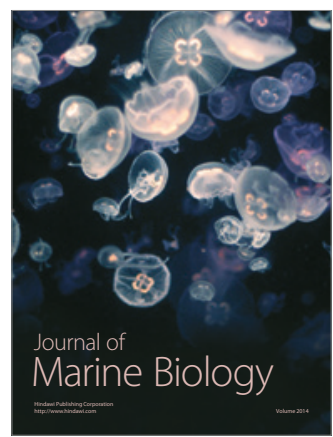

